\title{
Water quality assessment of a tropical river using water quality index (WQI), multivariate statistical techniques and GIS
}

\author{
Sanjoy Shil ${ }^{1} \cdot$ Umesh Kumar Singh ${ }^{1} \cdot$ Pankaj Mehta $^{2}$
}

Received: 28 January 2019 / Accepted: 23 September 2019 / Published online: 1 October 2019

(c) The Author(s) 2019

\begin{abstract}
Mahananda River is an important river in India and Bangladesh, as the people of both the countries use the water extensively, without sufficient and reliable information about water qualities and pollution status. The purpose of this study is to evaluate the water quality of the river and to analyse the suitability for drinking, agricultural and industrial uses. This is why this study on the Mahananda River is extremely important for the region. For this study, samples from fourteen sampling stations were collected in pre-monsoon and post-monsoon seasons in 2016 and water quality index (WQI), agriculture and industry-related indices were computed. WQI values designated two sampling stations out of fourteen sampling stations as 'very bad' category and another two sampling stations as 'bad' category. The $\mathrm{pH}$ values of some sampling stations slightly exceeded the upper permissible limit. USSL diagram analysis classified two samples of pre-monsoon season in C2S1 category which indicates a medium salinity and low sodium water. Magnesium hazard values of four sampling stations are above 50\% suggesting not suitable for irrigation. However, some indices like sodium per cent, residual sodium carbonate and residual sodium bicarbonate, Kelly's index, permeability index and potential salinity allow the water for use in irrigation purposes. Langelier Saturation Index and aggressive index values designate the water as moderately aggressive or non-aggressive. Ryznar Stability Index values designate the water as 'aggressive' or 'very aggressive' indicating unsuitability for industrial uses. Sampling stations S-1, S-2, S-8 and S-14 need special attention.
\end{abstract}

Keywords Sodium adsorption ratio $\cdot$ Residual sodium carbonate $\cdot$ Magnesium hazard $\cdot$ Aggressive index $\cdot$ Langelier index

\section{Introduction}

Surface water primarily consists of the water in streams, rivers, springs, ponds, lakes and in reservoirs. Surface water originates from precipitation on watershed areas and flows through streams and rivers and sometimes deposits in ponds and in lakes (Manahan 2010). This is the main source of water used in domestic, agricultural and industrial purposes worldwide (Khan et al. 2015). The rivers, among the aforesaid water bodies, are the major sources of water for human consumption, irrigation and industrial uses. The surface

Umesh Kumar Singh

umeshkumar.singh@visva-bharati.ac.in;

umeshjnu@gmail.com

1 Integrated Science Education and Research Centre (ISERC), Institute of Science, Visva-Bharati, Santiniketan, Birbhum, West Bengal 731235, India

2 Department of Environmental Science, Central University of Jammu, Samba, J\&K 181143, India water being exposed to anthropogenic influences and atmospheric deposition of pollutants becomes a very sensitive and critical issue in many countries (Sener et al. 2017; Kumar and Singh 2018). Anthropogenic influences, geochemical factors, chemical composition of river basin (Giridharan et al. 2010) and natural processes like interaction of water with lithogenic structure through which the river flows (Subramani et al. 2009; Sener et al. 2017) degrade surface water quality making it unsuitable for drinking, industry, agriculture and other purposes (Simeonov et al. 2003; Sánchez et al. 2007; Kazi et al. 2009).

The water quality of the river is deteriorated mainly by natural processes and through anthropogenic activities like discharge of industrial sewage, domestic wastewater and agricultural drainage water to the river (Singh and Kumar 2017). However, the main pollutants for river pollution are the industrial sewages, domestic wastewater and agricultural drainage water (Carpenter et al. 1998; Jarvie et al. 1998; Barakat et al. 2016). Since river is the main resource of freshwater to the human beings for use in different purposes,

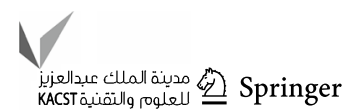


it is wise to protect and control the rivers from pollution and to have reliable information on water quality for effective management. Therefore, regular monitoring and evaluation of the water quality are required to protect, control and manage the river water from deterioration (Singh et al. 2005; Barakat et al. 2016).

Water quality generally encompasses the physical, chemical, biological, radiological and aesthetic characteristics of the water (Abdul et al. 2010; Ombaka and Gichumbi 2012). The evaluation of water quality of freshwater is essential because of the extreme demand and vulnerability to pollution in developing countries and also for the concern of being diminished in the near future (Ongley 2000; Yan et al. 2015). The water quality status of water is evaluated by a water quality index (WQI), a single unitless number distilled from a complex mathematical process from a large number of water quality parameters (Nives 1999; Pesce and Wunderlin 2000). The water quality of the river can also be evaluated with the help of individual parameters, but this is not in use because it requires a lot of concentrations of parameters (Chapman 1996). A large number of countries prefer the WQI method to assess overall river status (Bhargava 1983) because of being single valued and easy to understand (Mohamed et al. 2015).

Different authors and agencies have integrated different and varying number of water quality parameters to develop water quality indices (WQIs) of their own (Bhargava 1983; Pesce and Wunderlin 2000; Cude 2001). But most of them are developed on one that was developed by the U.S. National Sanitation Foundation, 2007 (Lermontov et al. 2009).

The river has played an important role since time immemorial in the development of human settlements, in agriculture, in riverine transportation and in cultural advancement (Priscoli 1998). Despite being developed in technologies, agriculture is still now an important sector contributing significantly in the national economic scenario of India and provides life support to a major portion of population (Singh 1983). Agriculture needs freshwater and freshwater is scare in many parts of India, due to the disparity of distribution of seasonal downpour especially in the arid and semi-arid regions. Moreover, the different pollution status differentiates the quality of the water, making the quantity limited for irrigation in different places in India (Ravikumar et al. 2011).

Some physicochemical parameters, some hydrogeochemical parameters calculated from the water quality parameters and a few graphical representations determine the suitability of the river water for agricultural uses (Sundaray et al. 2009). Agricultural science, preferably, deals with sodium concentration, salt content, nutrients level, presence of trace elements, acidity, alkalinity and hardness of the river water for better productivity. Fertility loss of the soil due to salinity variation has also become a serious problem all over the world (Etteieb et al. 2017).

Since river water is devoted to agricultural uses, its quality should be assessed to safeguard public health and environment (Igbinosa and Okoh 2009). Thus, comprehensive river water quality monitoring is a helpful tool not only to evaluate the suitability of surface water for irrigation, but also to ensure an efficient management of water resources and the protection of aquatic life (Kannel et al. 2007; Etteieb et al. 2017).

River water is not only used in drinking, irrigation and domestic purposes, but also used heavily in industrial set up. However, different industrial units require different water quality depending upon the kinds of industries and processes. The maintenance of water quality for industrial use is essential, especially in thermal electrical power stations and industrial boiler houses. One important parameter to assess water quality for industrial purposes is the Saturation Index (SI) as proposed by Langelier. Another important parameter is the Ryznar Stability Index. Besides these two parameters, TDS, hardness and concentration of the sulphate ion plays an important role in textile, paper and allied industries. Dairy, brewing and carbonated beverage industries should maintain the drinking water quality guidelines as it is consumed directly (Singh et al. 2008).

This study was conducted on the Mahananda River, the lifeline of North Bengal, situated in the state of West Bengal in India and in Bangladesh. Actually, the river is of interdistrict, interstate and international importance without having sufficient information about its water qualities and usefulness. For these reasons, this study on the Mahananda River has to be done.

The main objectives of this study are to (1) assess the physicochemical properties of the river water, (2) determine the water quality of the Mahananda River, through WQI analysis, and create WQI map based on GIS, (3) discuss the suitability of the water for drinking, agricultural and industrial purposes and (4) evaluate various agricultural parameters such as soluble sodium percentage (SSP), sodium adsorption ratio (SAR), permeability index (PI), Kelley's ratio (KR) and magnesium hazard (MH).

\section{Materials and method}

\section{Description of the study area}

Mahananda River, located in the northern part of West Bengal in India, has a total basin area of $20,600 \mathrm{~km}^{2}$ out of which $11,530 \mathrm{~km}^{2}$ is in India and the rest is in Bangladesh. It originates in the Himalayan range, from Mahaldiram Hill near Chimli, east of Kurseong in Darjeeling district at an elevation of $2100 \mathrm{~m}$ (Mandal 2013). The river is $360 \mathrm{~km}$ long, 
out of which $324 \mathrm{~km}$ is in India and $36 \mathrm{~km}$ is in Bangladesh. The river is trans-boundary in nature and travels through the Indian states of West Bengal and Bihar and then through Bangladesh. The right bank tributaries Mechi and Kankai cross out of Nepal (Mandal 2013; Galib et al. 2016). The river travels through a series of rocks for a short length in the hilly region of Darjeeling Himalaya and the rest over the new alluvium of Bengal Basin. The river enters into Bangladesh from Malda district of India and joins the Padma River (part of Ganges in Bangladesh) at Nawabganj Sadar Upazila of Nawabganj district in Bangladesh (Mandal 2013; Galib et al. 2016).

The study area extends from $26^{\circ} 45^{\prime} 30.48^{\prime \prime}$ to $24^{\circ} 57^{\prime} 29.2^{\prime \prime} \mathrm{N}$ longitude and $87^{\circ} 48^{\prime} 17.79^{\prime \prime}$ to $88^{\circ} 26^{\prime} 0.73^{\prime \prime} \mathrm{E}$ altitude (Fig. 1). The water sampling stations S2, S8, S13 and $\mathrm{S} 14$ are exposed to urban run-off while the rest stations are exposed to run-off from rural human habitats and agricultural fields. Siliguri town, Kishanganj, Dalkhola, Barsoi, Old Malda and Malda Town are the important urban areas beside this river.

\section{Geological settings of the area}

Mahananda River basin is actually a part of the Bengal Basin, the world's largest sedimentary depositories (Ameen et al. 2007). The river runs through five distinct geological setups from north to south (Fig. 1). (1) Precambrian metasedimentary rocks and younger felsic intrusions, locally known as Darjeeling gneiss, are composed of kyanite, sillimanites, carbonaceous micaschists, garnetiferrous micaschists, migmatitic gneiss, etc. (Mukherjee et al. 2009; Heroy et al. 2003). (2) Precambrian metasedimentary rocks and limestone, popularly known as rocks of Daling series, situated at the southward, are parallel to the previous rock layer and extend in the east-west direction. The layer is composed mainly of slates, phyllites and of lower metamorphic grades of chlorite-sericite schist, quartz-sericite schist chlorite and quartz schists (Mukherjee et al. 2009; Heroy et al. 2003; Banerjee 1955). (3) Gondwana, also known as Damuda series in Darjeeling geology, is parallel to the Daling series and situated in the south. The layer is mainly consists of sandstone shales and quartzite in which the sandstones are micaceous and feldspathic with red, grey buff or brownish shades (Dash 1947; Banerjee 1955). (4) Miocene Siwalik sandstone, found in the south and adjacent to the Gondwana series, was originated in the Pliocene-Mid-Miocene age and is composed of micaceous sandstone, arkosic sandstones, bluish and greyish siltstones, conglomerates, etc. (Banerjee 1955; Heroy et al. 2003; Mukherjee et al. 2009). (5) Quaternary alluvium, formed by deposited sediments from the Ganges-Brahmaputra-Meghna (GBM) Rivers, has two major units, the Pleistocene uplands composed of 'old alluvium' and deltaic lowlands (flood plains) of 'recent alluvium' (Morgan and McIntire 1959). Mahananda River flows
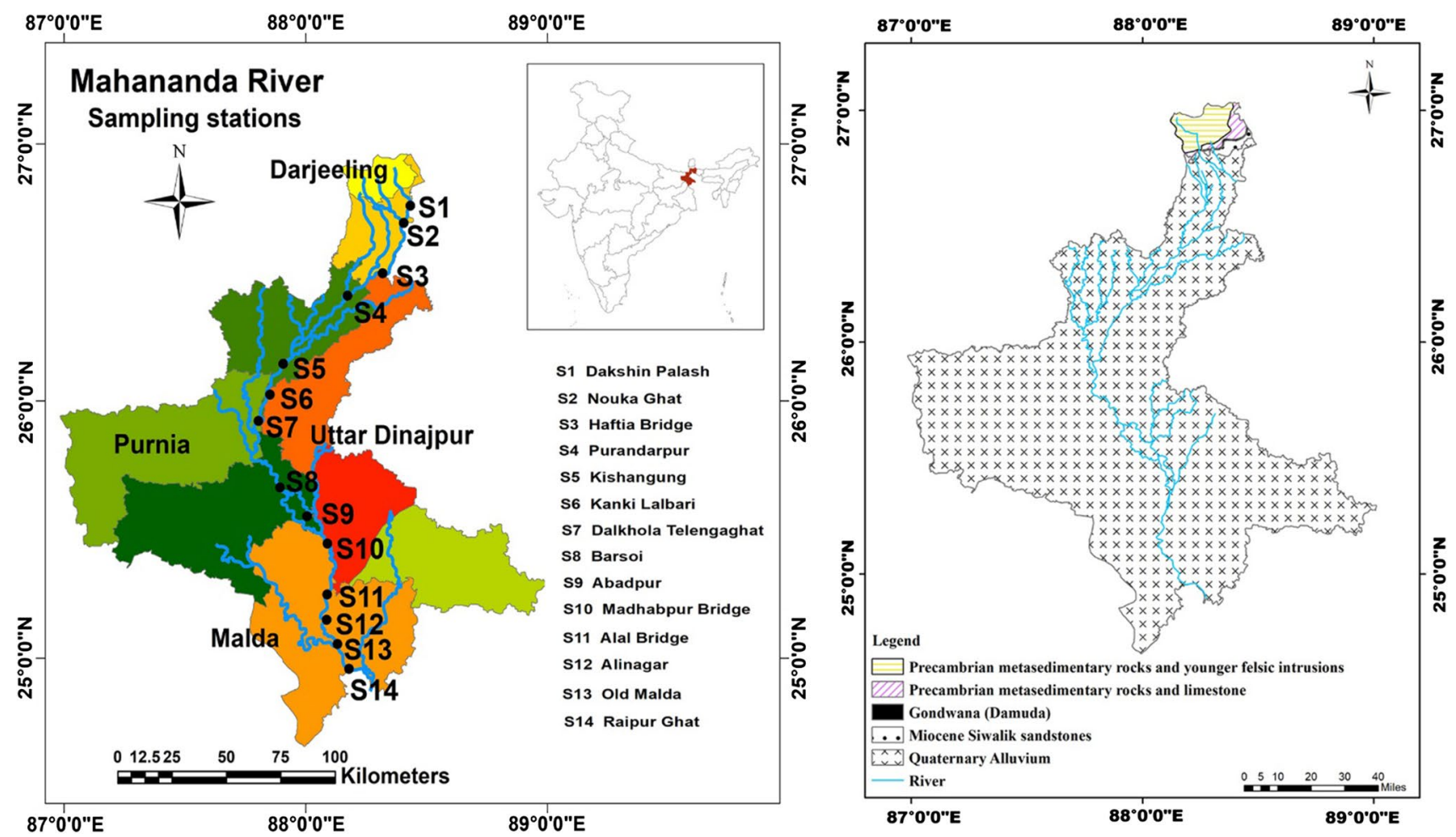

Fig. 1 Map of sampling stations and geological settings of the study area 
through one of such flood plains in between the Rajmahal hill and the Barind (Morgan and McIntire 1959). The common rocks and minerals found here are kaolinite, smectite, amphibole, garnet, epidote, illite and chlorite, but amphibole (Mukherjee et al. 2009).

\section{Sampling and analytical procedure}

The water samples were collected in pre-monsoon and post-monsoon period of 2016 from previously selected 14 (fourteen) sampling stations in washed polypropylene bottles (manufactured by Tarson, India). The sampling stations were selected on the basis of uniform distance, with slight deviation depending upon the geographic condition and ease of access. Coordinates of the sampling stations were recorded by Global Positioning System (GPS). Some physicochemical parameters like temperature and $\mathrm{pH}$ were determined in the sampling sites by laboratory mercury thermometer and pocket $\mathrm{pH}$ meter (HANNA, USA), respectively. The water samples were collected manually from a depth of $20 \mathrm{~cm}$ from the surface of the water, preferentially where the flow of the water was high, to obtain good homogenised samples (Rakotondrabe et al. 2018). After collecting the samples and making the bottles airtight, the samples were transported to the laboratory with favourable temperature $\left(<4{ }^{\circ} \mathrm{C}\right)$ following the procedures described in APHA (2012). In the laboratory, dissolved oxygen (DO), electrical conductivity (EC) and total dissolved solid (TDS) were determined immediately by Thermo-Scientific Orion 5 Star instrument (Thermo-Scientific Inc.). The samples were filtered with ash-less Whatman (42) 100-mm filter paper, and $\mathrm{Na}$, K and Ca were determined by flame photometer (ELCO-CL361). All the reagents used for analytical purposes were of analytical grade (Merck, India) for higher accuracy and precision. For quality control, procedural blank, sample duplicates and repeating experiments, according to the requirement, were done during the analysis period. A little part of the sample was filtered by nylon membranes (pore size $0.22 \mu \mathrm{m}$, diameter $13 \mathrm{~mm}$ ) filter paper (RANKEM, India) for analysis by ion chromatography. Fluoride $\left(\mathrm{F}^{-}\right)$, chloride $\left(\mathrm{Cl}^{-}\right)$, bromide $\left(\mathrm{Br}^{-}\right)$, nitrate $\left(\mathrm{NO}_{3}{ }^{-}\right)$, phosphate $\left(\mathrm{PO}_{4}{ }^{3-}\right)$, sulphate $\left(\mathrm{SO}_{4}{ }^{2-}\right)$, carbonate $\left(\mathrm{CO}_{3}{ }^{2-}\right)$ and bicarbonate $\left(\mathrm{HCO}_{3}{ }^{-}\right)$were determined by ion chromatography (Metrohm, Switzerland).

\section{Analytical methods}

\section{Water quality}

The water quality index (WQI) is considered as an efficient mean to reflect the water quality comprehensively, integrating the different water quality parameters into a single-valued unitless integer (Sener et al. 2017; Wang et al. 2017). The raw analytical results of various water quality parameters with different values and units are transformed into a single value by a special type of mathematical averaging function (Cude 2001).

Some researchers and some countries proposed different WQIs considering different water quality parameters, and the indices are applied worldwide. The WQI was first proposed by Horton (1965) and was used for drinking water quality analysis (Brown et al. 1970; Misaghi et al. 2017; Kumar et al. 2018). Later on, Pesce and Wunderlin (2000) also proposed a WQI method which is used by many researchers. Some WQIs proposed by some countries are National Sanitation Foundation Water Quality Index (NSFWQI) by USA, the Florida Stream Water Quality Index (FWQI), the British Columbia Water Quality Index (BCWQI) by Britain, the Canadian Water Quality index (CWQI) and the Oregon Water Quality Index (OWQI) as described by Cude (2001). WQI, here, has been calculated (Eq. 1) following the method given by Pesce and Wunderlin (2000) and is given by

$\mathrm{WQI}_{\mathrm{sub}}=k \frac{\sum_{i=1}^{n} C_{i} \cdot P_{i}}{\sum_{i=1}^{n} P_{i}}$

$C_{i}$ is the normalised value assigned to each parameter and $P_{i}$ is the relative weight of each parameter. $P_{i}$ has the values ranging from 1 to 4 , where value 4 represents the most important parameter to aquatic life and 1 is assigned to the least one. $k$ is a subjective constant and may have values ranging from 1.0 to 0.25 depending on the visual impression of river contamination of the researcher. The value 1.0 is assigned to water without apparent contamination, and 0.25 is assigned to highly contaminated water.

\section{Pearson's correlation}

Pearson's correlation analysis is an important statistical tool to exhibit the degree of dependency of one variable to the others (Belkhiri et al. 2011). Actually, correlation coefficient is used to measure the interrelation and extent of associations among the variables. Correlation coefficient value +1 indicates a perfect relationship between the variables, and -1 indicates perfect relationship, but the variables vary inversely (Mudgal et al. 2009) and a zero value means no relationship between the variables (Mudgal et al. 2009) at a significant level of $p<0.05$. Generally, Pearson's correlation coefficient values $r>0.7$ are considered as strong correlation, whereas $r$ values between 0.5 and 0.7 are considered as moderate correlation. Pearson's correlation matrix clearly represents the dependency of variables with each other.

\section{Irrigation water qualities}

The suitability of water for irrigation purpose depends on the physical and chemical properties of the water, especially 
on the dissolved salts. Plant roots uptake water that includes a little amount of dissolved salts, leaving major portion of the salts at the root vicinity. Water naturally evaporates, and the dissolved salts are left in the soil complex. Within a few years, the gradual salt accumulation increases in the soil (Srinivasamoorthy et al. 2014), causing salinity hazard and toxicity. However, some dissolved salts or constituents are useful for plants growth. The suitability of irrigation water is assessed mainly in terms of the presence of undesirable dissolved salts or constituents, and in some limited cases assessed on plant nutrients (FAO 2008; Haritash et al. 2016). The major river water parameters, which help to decide the suitability for irrigation, are $\mathrm{pH}, \mathrm{EC}$, TDS, hardness, sodium, potassium, calcium, magnesium, chloride, sulphate, nitrate, carbonate, bicarbonate, etc. (Sundaray et al. 2009; Haritash et al. 2016). Some calculated indices that also help to assess the suitability of irrigation water are discussed in the following parts accordingly.

Sodium adsorption ratio (SAR) Sodium adsorption ratio (SAR) also expressed as sodium content or alkali hazard is an important index for determining the suitability of water used in irrigation (Srinivasamoorthy et al. 2014). Excessive sodium in water imparts undesirable effects on the soil properties and decreases soil permeability (Kelly 1951; Sundaray et al. 2009). Higher salinity interferes with the osmotic activities, thus reduces the absorption of water and nutrients from the soil, impedes water from reaching the leaves of plants and prevents plant metabolism (Arumugam and Elangovan 2009). High sodium content in water leads to genesis of alkaline soil. The SAR is the measure of the relative proportion of sodium ions to the calcium and magnesium ions in a water sample. Actually, SAR reflects the sodium hazard and is computed using the formula (Eq. 2) given by U.S. Department of Agriculture Salinity Laboratory in 1954 (Wilcox 1955; Hem 1970) as:

$\mathrm{SAR}=\frac{\mathrm{Na}^{+}}{\sqrt{\frac{\mathrm{Mg}^{2+}+\mathrm{Ca}^{2+}}{2}}}$

Ionic concentrations are measured in $\mathrm{meq} / \mathrm{L}$. Based on the SAR values, water is classified into four classes. SAR $<10$ is considered as excellent (sodium hazard class $\mathrm{S}-\mathrm{I}$ ), SAR $=10-18$ is considered as good (class S-2), $\mathrm{SAR}=19-26$ is considered as doubtful/fair poor (class S-III), and SAR $>26$ of water is considered unsuitable (class S-IV) (Richards 1954; Wilcox 1955).

Sodium percentage ( $\mathrm{Na} \%)$ The irrigation water is also classified on the basis of soluble sodium content, because higher sodium content in irrigation water reduces the permeability (Todd 1980; Sundaray et al. 2009). Percentage of $\mathrm{Na}$ ( $\mathrm{Na} \%$ ) is widely used to determine the suitability of water for agricultural purposes. This term is also referred to as the soluble sodium per cent (SSP) (Wilcox 1955). It is defined and is also calculated by the following equation (Eq. 3):

$\mathrm{Na} \%=\frac{\mathrm{Na}^{+} \times 100}{\left(\mathrm{Ca}^{2+}+\mathrm{Mg}^{2+}+\mathrm{Na}^{+}+\mathrm{K}^{+}\right)}$

All the concentrations are expressed in meq/L. Based on sodium per cent, water is classified as safe or unsafe. $\mathrm{Na} \%>60$ is considered unsafe, and $\mathrm{Na} \%<60$ is considered safe for agricultural activities (Eaton 1950; Ravikumar et al. 2011).

Residual sodium carbonate (RSC) Concentrations of carbonate and bicarbonate play an important role in determining the suitability of water for irrigation purposes. When the total carbonate concentration exceeds the total concentrations of calcium and magnesium and the excess carbonate (residual) concentration is too high, the carbonate ions combine with the calcium and magnesium ions to form a scale, a solid material, which then settles out of the water. As the calcium and magnesium settle out of the water as solid scales, the relative abundance of sodium increases creating deteriorating consequences on the plants. The quantity of carbonate and bicarbonate in excess of alkaline earth metals (calcium and magnesium) is denoted by 'residual sodium carbonate' (RSC) (Sundaray et al. 2009; Ravikumar et al. 2011). The term was proposed by Eaton (1950) and is determined by the method as suggested by Richards (1954). Residual sodium carbonate is calculated by the following formula (Eq. 4) (Wilcox 1955).

$\mathrm{RSC}=\left(\mathrm{CO}_{3}^{-2}+\mathrm{HCO}_{3}^{-}\right)-\left(\mathrm{Ca}^{2+}+\mathrm{Mg}^{2+}\right)$

All the concentrations are expressed in meq/L.

Residual sodium bicarbonate (RSBC) Most of the natural waters do not contain carbonate ions in appreciable quantity, and bicarbonate ions do not precipitate magnesium an ion, so the alkalinity hazard, according to Gupta and Gupta (1987), will be determined by an index called residual sodium bicarbonate (RSBC) and is calculated by the following equation (Eq. 5) (Ravikumar et al. 2011).

$\mathrm{RSBC}=\mathrm{HCO}_{3}^{-}-\mathrm{Ca}^{2+}$

The concentrations of various ions are expressed in $\mathrm{meq} / \mathrm{L}$.

Magnesium hazard (MH) Calcium and magnesium ions maintain a state of equilibrium in most natural water (Hem 1989). Calcium and magnesium are not chemically equivalent especially in the soil system. A higher concentration 
of $\mathrm{Mg}$ ion in water is usually due to the higher exchangeable $\mathrm{Na}$ ion present in irrigated soils. High concentration of $\mathrm{Mg}$ ion present in water adversely affects the soil quality, making the soil alkaline, which results in low crop yield (Sundaray et al. 2009). The adverse effect of magnesium in irrigated water is measured as the magnesium ratio. Paliwal (1972) introduced an index 'magnesium hazard' for determining the adverse effects of magnesium in irrigation water and is calculated as magnesium ratio (MH) using the formula (Eq. 6) (Sundaray et al. 2009; Ravikumar et al. 2011). The concentrations of calcium and magnesium ions are measured in meq/L.

$\mathrm{MH}=\frac{\mathrm{Mg}^{+}}{\mathrm{Ca}^{2+}+\mathrm{Mg}^{2+}} \times 100$

Kelly's index (KI) Suitability of water quality for irrigation purposes is also determined on the basis on Kelly's index. In Kelly's index, sodium measured against calcium and magnesium (Kelly 1940). KI is calculated by the following formula (Eq. 7) (Srinivasamoorthy et al. 2014)

$\mathrm{KI}=\frac{\mathrm{Na}^{+}}{\mathrm{Ca}^{2+}+\mathrm{Mg}^{2+}}$

where ion concentrations are expressed in meq/L.

Kelly's index indicates an excess quantity of sodium in water. Therefore, water with Kelly's index value less than one $(\mathrm{KI}<1)$ is acceptable for irrigation, whereas value greater than one $(\mathrm{KI}>1)$ indicates excess sodium in water and value less than two $(\mathrm{KI}<2)$ indicates sodium deficiency in water (Kelly 1940; Sundaray et al. 2009).

Permeability index (PI) Permeability index (PI) is also used to determine the suitability of the irrigation water. The permeability of soil is affected by long-term exposure of irrigation water containing high quantity of sodium, calcium, magnesium and bicarbonate ions (Ravikumar et al. 2011; Srinivasamoorthy et al. 2014). Doneen (1964) introduced permeability index (PI) for assessing the suitability of irrigation water and is calculated by the following formula (Eq. 8) (Arumugam and Elangovan 2009).

$\mathrm{PI}=\frac{\left(\mathrm{Na}^{+}+\sqrt{ } \mathrm{HCO}_{3}^{-}\right) \times 100}{\left(\mathrm{Ca}^{2+}+\mathrm{Mg}^{2+}+\mathrm{Na}^{+}+\mathrm{K}^{+}\right)}$

The concentrations are expressed in meq/L. Water is classified into three classes based on the PI values. Class I (PI $>75 \%)$ is considered as suitable for irrigation, class II $(\mathrm{PI}=25-75 \%)$ is considered as moderately suitable for irrigational uses, and class III $(\mathrm{PI}<25 \%)$ is unsuitable (Sundaray et al. 2009; Das and Nag 2015).
Potential salinity Salts of low solubility in the irrigation water are precipitated out and accumulated on the soil by each successive cultivation. Only the highly soluble salts remain dissolved in the water and increase the salinity. Each year, the salinity of the river is gradually increasing and has now been recognised as a major problem to the downstream water users (Kumarasamy et al. 2013a). 'Potential salinity is defined as the chloride concentration plus half of the sulphate concentration' (Doneen 1962; Ravikumar et al. 2011) (Eq. 9).

Potential Salinity $(\mathrm{PS})=\mathrm{Cl}^{-}+\frac{1}{2} \mathrm{SO}_{4}^{2-}$

The concentrations are expressed in meq/L.

The PS problem is generally more prominent in the estuarine zone than in the freshwater zone, due to the presence of excessive chlorides of the sea water (Kumarasamy et al. 2013a).

\section{Suitability for industrial purpose}

Industries, like thermal power plants, boiler feed water, manufacturing processes, etc., use a large quantity of water. However, the water quality required for different industries varies with the forms of industries. Some industries require water quality capable of preventing pipe corrosion and scale formation, whereas some industries like dairy, brewing and carbonated beverage require drinking water standards (Singh et al. 2008).

Scale formation is one of the major problems in heavy industries. For monitoring scale formation, Langlier in 1936 introduced Saturation Index (SI) to evaluate whether and to what extent a water is scale forming. Actually, the Langlier Satuaration Index (LSI) predicts the stability of calcium carbonate in water, i.e. whether a water will precipitate, dissolve or be in equilibrium with calcium carbonate (Haritash et al. 2016). The LSI calculated (Eq. 10) as the difference between the actual $\mathrm{pH}$ of the water and the $\mathrm{pH}$ saturated with calcium carbonate $\left(\mathrm{pH}_{\mathrm{s}}\right)$ (Eq. 11).

LSI $=\mathrm{pH}($ measured $)-\mathrm{pH}_{\mathrm{s}}($ Langelier 1936 $)$.

where

$\mathrm{pH}_{\mathrm{s}}=A+B-C-D$

The $\mathrm{pH}_{\mathrm{s}}, A, B, C$ and $D$ are calculated according the method described by Langelier (1936). If the $\mathrm{pH}$ of the water is less than the saturation $\mathrm{pH}_{\mathrm{s}}$, the LSI is negative and the water is supposed to have very limited scale forming potential. If the $\mathrm{pH}$ exceeds $\mathrm{pHs}$, the LSI is positive, it indicates the water is supersaturated with calcium carbonate and the water has a scale forming tendency. The larger 
the positive LSI index value, more is the scale forming potential (Haritash et al. 2016).

Another important index, the aggressive index (AI), developed by Langelier to monitor water flowing in asbestos pipe. Sometimes it is used as substitute of the Langelier index and it indicates of the corrosivity of the water. The AI is calculated by summing up the actual $\mathrm{pH}$, calcium hardness and total alkalinity. The AI is simple and convenient than the LI, because it does not include the effects of temperature (Langelier 1936).

$\mathrm{AI}$ is calculated by the following formula (Eq. 12):

$\mathrm{AI}=\mathrm{pH}_{\text {actual }}+C+D$

where $C$ and $D$ values are calculated by the method given by Langelier (1936).

The stability index (SI) was proposed by Ryznar to avoid the misinterpretation of positive saturation index that is usually considered as non-corrosive or scale forming.

Ryznar stability index (RSI) is defined (Eq. 13) as:

$\mathrm{RSI}=2 \mathrm{pH}_{\mathrm{s}}-\mathrm{pH}$

where $\mathrm{pH}$ is the measured $\mathrm{pH}$ of the solution and the $\mathrm{pH}_{\mathrm{s}}$ is the $\mathrm{pH}$ at saturation point, calculated by Langelier's method. The stability index value is always positive for all waters. The behaviour of natural water and treated water having same stability index values of 5.5 or less will be similar and prominent scale forming. Waters with a stability index value of 9.5 will have a limited potential of calcium carbonate scale formation and may have severe corrosive potential at higher temperatures (Ryznar and Langelier 1944; Haritash et al. 2016).

\section{Results and discussion}

In this study, water quality indices of Mahananda River water were calculated by the following Pesce and Wunderlin (2000) method for each sampling stations and for both pre-monsoon and post-monsoon seasons of 2016. To calculate the WQI, water quality variables, viz. temperature, $\mathrm{pH}, \mathrm{EC}, \mathrm{DO}$, hardness, TDS, $\mathrm{Ca}, \mathrm{Mg}$, chloride, nitrate, phosphate and sulphate were considered. The highest weight value of 4 was assigned to parameters such as DO and TDS which have the prominent effects on water quality (Pesce and Wunderlin 2000). The WQI values varied from 17.63 to 93.50 in the pre-monsoon season and from 18.25 to 94.50 in the post-monsoon season. Jonnalagadda and Mhere (2001) classified water according to WQI values into the following five classes, $0-25=$ very bad, $26-50=$ bad, $51-70=$ medium, $71-90=$ good , and $91-100=$ excellent. Therefore, Mahananda River water ranges from 'very bad' to 'excellent' quality.
Sampling stations S-2 and S-8 designated as very bad; S-1 and S-14 as bad, S-9, S-12 and S-13 as medium; S-3, S-4, S-5, S-6 and S-7 as good; and S-10 and S-11 as excellent in the pre-monsoon season. In post-monsoon season, S-2 and S-8 regarded as very bad; S- 1 and S-14 as bad; S-12 and S-13 as medium; S-3, S-4, S-5, S-6, S-9 and S-10 as good; and S-7 and S-11 as excellent. The sampling station S-2 represents very bad water quality, because it situated in the downstream of Siliguri city and is thought to receive the municipal effluents. The water looks like municipal drain water. The sampling station S-8 also represents very bad water, because water here is almost static and pollutants did not get disperse. S-1 is situated at upstream proximity of Siliguri city. S-1 is low densely populated region with little and narrow flow of water. S-14 is situated at a few kilometres distant in the downstream of Malda Town. The river, here, also receives municipal effluents but get a scope of being dispersed and represents a bad water. Quantitatively, the post-monsoon water quality is slight better, because a part of the pollutants is diluted and washed away with heavy rain water. The exact variations of the WQI of both the seasons are shown in the geospatial map (Fig. 10).

To know the hydrogeochemical characteristics of the study area and water, the analytical values were plotted on Piper diagram (Piper 1944). Piper trilinear diagram includes two triangles, one showing cations and the other showing anions and a diamond-shaped area to show a combined position of cations and anions. The combined single position of the diamond-shaped area helps us to draw inference and to classify the water on the basis of the hydrogeochemical characteristics. The diamond-shaped area of Piper diagram is divided into four major parts, each part representing and explaining a particular type of variation or domination of cations and anions. The four parts are (1) $\mathrm{Ca}^{2+}-\mathrm{Mg}^{2+}-\mathrm{Cl}^{-}-\mathrm{SO}_{4}{ }^{2-}$, (2) $\mathrm{Na}^{+}-\mathrm{K}^{+}-\mathrm{Cl}^{-}-\mathrm{SO}_{4}{ }^{2-}$, (3) $\mathrm{Na}^{+}-\mathrm{K}^{+}-\mathrm{HCO}_{3}{ }^{-}$and (4) $\mathrm{Ca}^{2+}-\mathrm{Mg}^{2+}-\mathrm{HCO}_{3}{ }^{-}$. All the samples of this study of both the seasons fall in the category (4) $\mathrm{Ca}^{2+}-\mathrm{Mg}^{2+}-\mathrm{HCO}_{3}{ }^{-}$representing a dominance of calcium, magnesium and carbonate ions in the water. The sources of this type of waters may be a typical shallow freshwaters (Figs. 2, 3) (Guettaf et al. 2014). S-2, S-8, S-9, S-10, S-13 and S-14 sampling stations are shallow freshwater stations with rooted aquatic vegetation along the banks.

The box and whisker plots of the water parameters have also been drawn of for two seasons to show the variations of studied parameter values and are given in Figs. 4 and 5 . Box and whisker plots show that $\mathrm{pH}$, acidity in pre-monsoon and $\mathrm{pH}, \mathrm{DO}$, acidity, $\mathrm{K}$ and nitrate in post-monsoon have almost the same trend. These parameters do not vary significantly along the sampling stations. The rest parameters vary with the sampling stations. The number of parameters of varying concentration is greater in pre-monsoon than that of the post-monsoon season. This is probably because

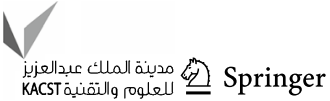


Fig. 2 Piper diagram of premonsoon season 2016

Fig. 3 Piper diagram of postmonsoon season 2016
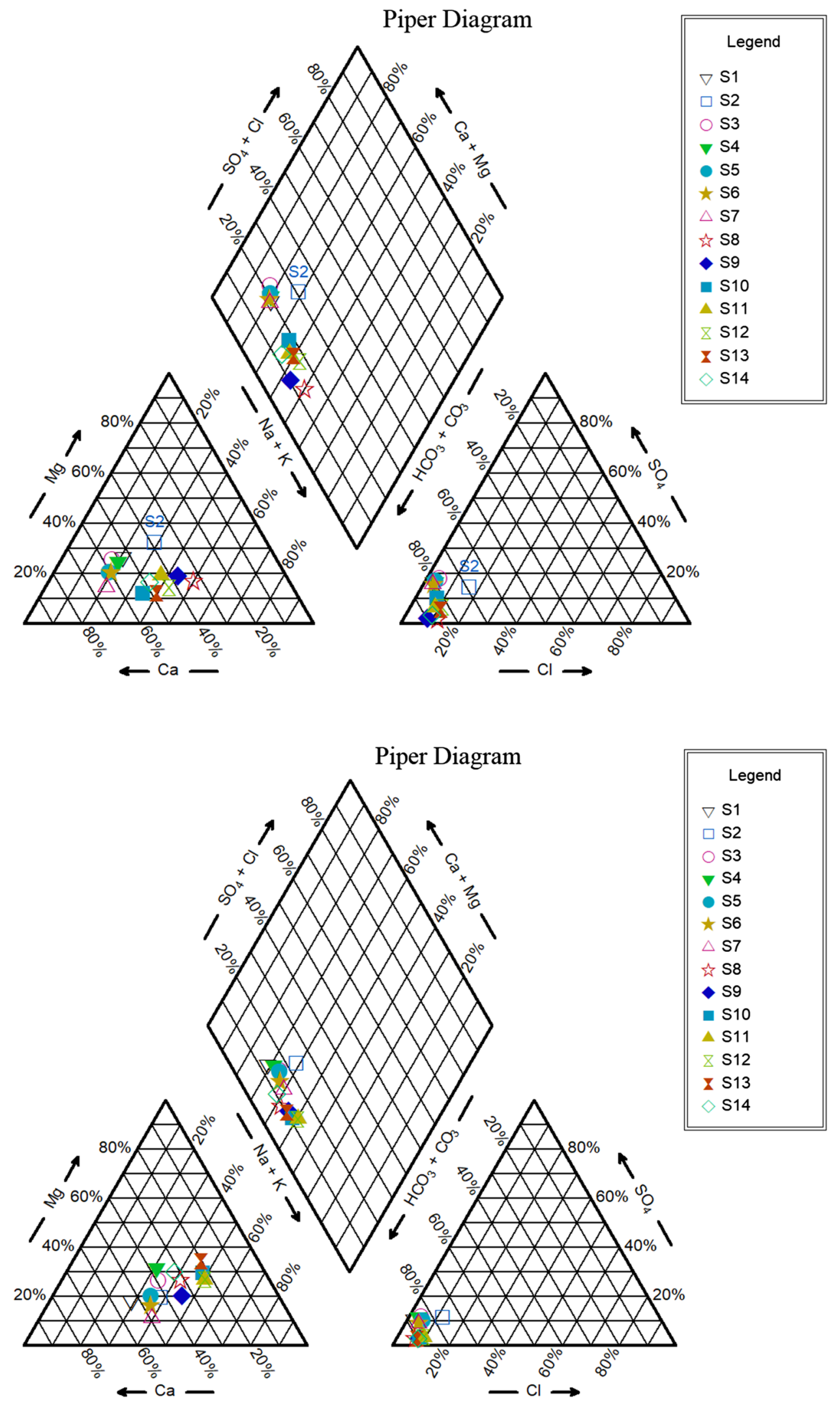
Fig. 4 Box plot variables of premonsoon season

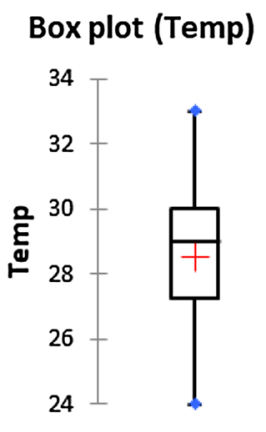

Box plot (Acidity)

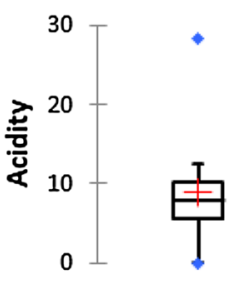

Box plot (Na)
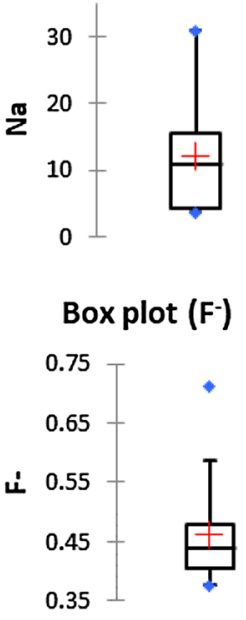

Box plot $\left(\mathrm{PO}_{4}^{-3}\right)$

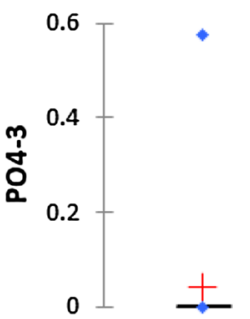

Box plot (pH)

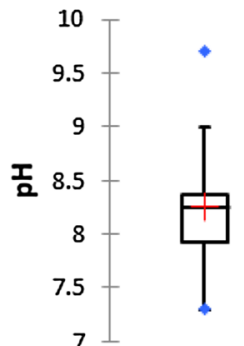

Box plot (Alkalinity)

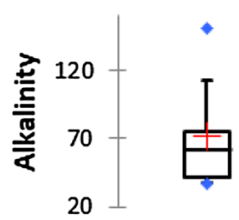

Box plot (K)

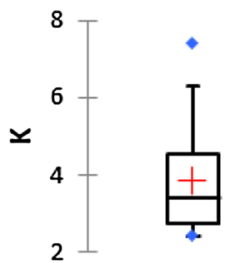

Box plot (Cl)

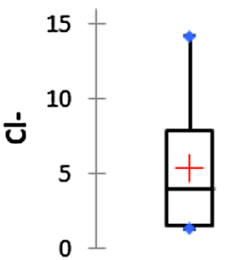

Box plot $\left(\mathrm{SO}_{4}^{-2}\right)$

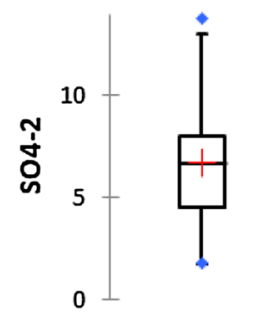

Box plot (EC)

Box plot (DO)

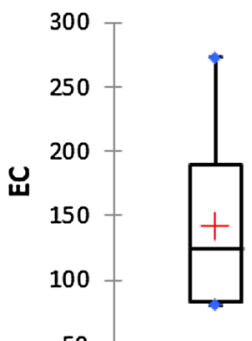

50

Box plot

(Hardness)
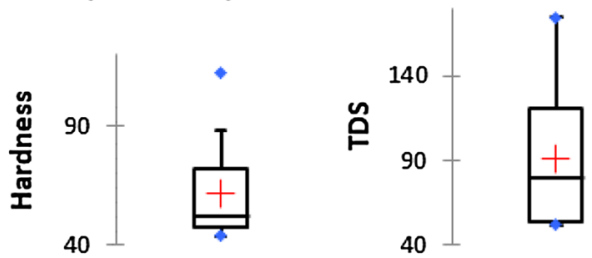

Box plot (Mg)

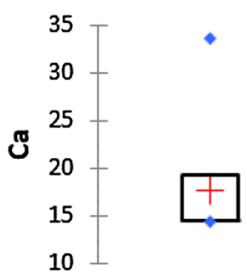

Box plot $(\mathrm{Br})$
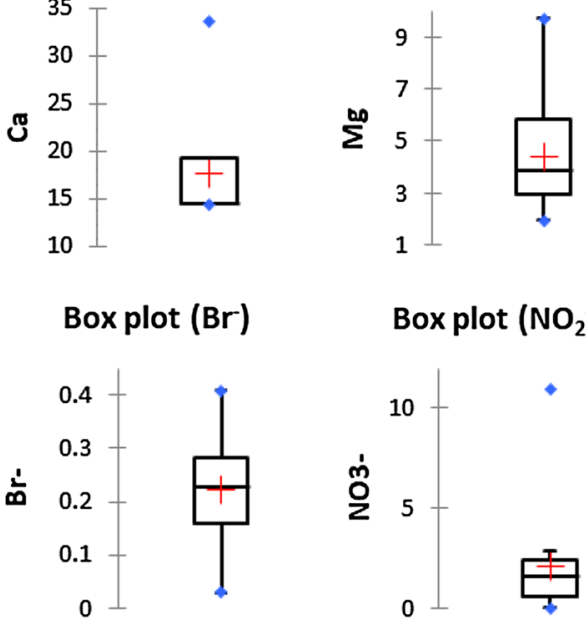

Box plot $\left(\mathrm{NO}_{2}^{-}\right)$
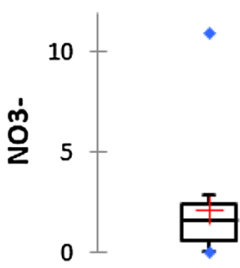

Box plot $\left(\mathrm{HCO}_{3}{ }^{-}\right)$

Box plot $\left(\mathrm{CO}_{3}^{-2}\right)$

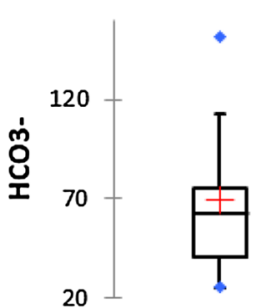

of heavy water of monsoon and flow of water during rainy season homogenise the water of the river (Zhang et al. 2009; Kumarasamy et al. 2013b).

Pearson correlation matrix and other statistical analysis were performed by using XLSTAT 2016 software on the water quality parameters to evaluate the relationship among the variables. The actual values of the variables (temperature, $\mathrm{pH}, \mathrm{EC}, \mathrm{DO}, \mathrm{TDS}$, hardness, acidity, alkalinity, $\mathrm{Na}, \mathrm{K}, \mathrm{Ca}, \mathrm{Mg}$, fluoride, chloride, bromide, nitrate, sulphate, phosphate, carbonate and bicarbonate) were taken for statistical analysis. Pearson correlation matrix analysis represents that strong positive correlations exist between EC-alkalinity, EC-TDS, EC-Cl, alkalinity-hardness, alkalinity-Na, alkalinity-chloride, alkalinity-bromide, 
Fig. 5 Box plot of variables of post-monsoon season

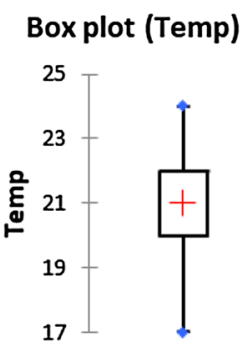

Box plot (Acidity)
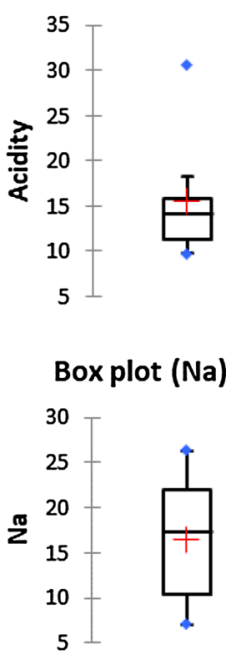

Box plot (F-)

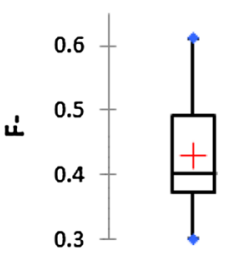

Box plot $\left(\mathrm{PO}_{4}^{-3}\right)$

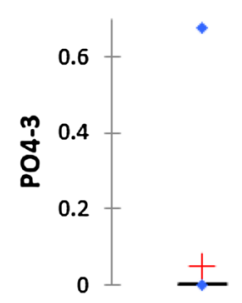

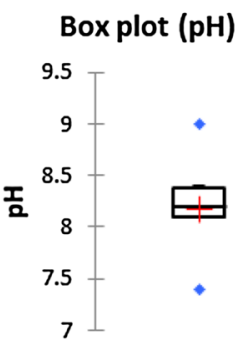

Box plot (Alkalinity)

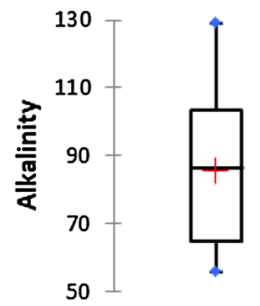

Box plot (K)

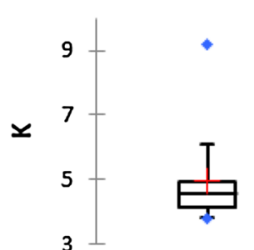

Box plot $\left(\mathrm{Cl}^{-}\right)$

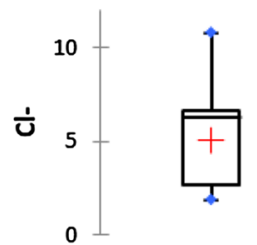

Box plot $\left(\mathrm{SO}_{4}^{-2}\right)$

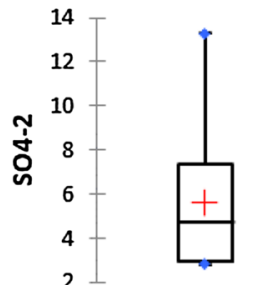

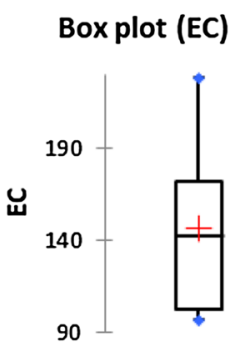

Box plot

(Hardness)
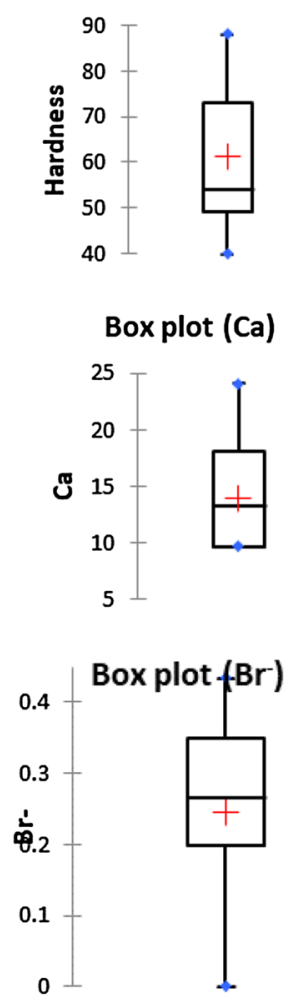

Box plot $\left(\mathrm{HCO}_{3}{ }^{-}\right)$

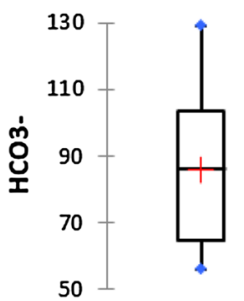

alkalinity-carbonate, hardness-Ca, TDS-Na, TDS-Cl, $\mathrm{Na}-\mathrm{Cl}, \mathrm{Na}-\mathrm{Br}$, etc., of pre-monsoon season. In the postmonsoon season, EC-alkalinity, EC-hardness, EC-TDS, EC-bicarbonate, DO-K, alkalinity-bicarbonate, alkalinity-hardness and hardness-TDS were found to exist positively correlated. This signifies that the parameters change with direct proportionality. Some parameters were found to be in fair negative correlation signifying that these parameters change with inverse proportionality. Actual values of the Pearson's correlation coefficients are given in the correlation matrix tables (Tables 1,2).

Principal component analysis (PCA) was conducted to analyse the compositional pattern of the variables on the entire dataset and to reduce the dataset to some influencing factors by avoiding some insignificant data (Wang et al. 2015, 2017). In this study, first three principle components 
Table 1 Pearson correlation matrix of pre-monsoon water parameters

\begin{tabular}{|c|c|c|c|c|c|c|c|c|c|c|}
\hline Variables & Temp & $\mathrm{pH}$ & $\mathrm{EC}$ & DO & Acidity & Alka. & $\mathrm{TH}$ & TDS & $\mathrm{Na}$ & K \\
\hline Temp & 1 & & & & & & & & & \\
\hline $\mathrm{pH}$ & 0.245 & 1 & & & & & & & & \\
\hline $\mathrm{EC}$ & 0.512 & -0.334 & 1 & & & & & & & \\
\hline DO & 0.446 & 0.751 & -0.012 & 1 & & & & & & \\
\hline Acidity & 0.241 & -0.657 & 0.776 & -0.434 & 1 & & & & & \\
\hline Alka. & 0.543 & -0.208 & 0.968 & 0.134 & 0.766 & 1 & & & & \\
\hline $\mathrm{TH}$ & 0.360 & -0.319 & 0.848 & -0.015 & 0.494 & 0.771 & 1 & & & \\
\hline TDS & 0.512 & -0.334 & 1.000 & -0.012 & 0.776 & 0.968 & 0.848 & 1 & & \\
\hline $\mathrm{Na}$ & 0.597 & -0.160 & 0.920 & 0.219 & 0.726 & 0.960 & 0.626 & 0.920 & 1 & \\
\hline $\mathrm{K}$ & 0.405 & -0.370 & 0.847 & -0.121 & 0.500 & 0.707 & 0.873 & 0.847 & 0.664 & 1 \\
\hline $\mathrm{Ca}$ & 0.402 & -0.147 & 0.773 & 0.260 & 0.385 & 0.769 & 0.929 & 0.773 & 0.630 & 0.706 \\
\hline $\mathrm{Mg}$ & 0.207 & -0.484 & 0.736 & -0.408 & 0.523 & 0.574 & 0.844 & 0.736 & 0.457 & 0.888 \\
\hline $\mathrm{F}^{-}$ & 0.409 & -0.238 & 0.775 & -0.053 & 0.824 & 0.834 & 0.408 & 0.775 & 0.858 & 0.424 \\
\hline $\mathrm{Cl}^{-}$ & 0.514 & -0.408 & 0.952 & -0.067 & 0.766 & 0.889 & 0.732 & 0.952 & 0.908 & 0.859 \\
\hline $\mathrm{Br}^{-}$ & 0.760 & -0.128 & 0.880 & 0.274 & 0.637 & 0.905 & 0.685 & 0.880 & 0.912 & 0.681 \\
\hline $\mathrm{NO}_{3}^{-}$ & -0.101 & -0.586 & 0.253 & -0.734 & 0.288 & 0.028 & 0.359 & 0.253 & -0.038 & 0.576 \\
\hline $\mathrm{PO}_{4}^{3-}$ & -0.056 & -0.452 & 0.274 & -0.564 & 0.156 & 0.030 & 0.385 & 0.274 & 0.001 & 0.660 \\
\hline $\mathrm{SO}_{4}^{2-}$ & -0.409 & -0.274 & -0.303 & -0.565 & -0.256 & -0.481 & 0.068 & -0.303 & -0.635 & 0.042 \\
\hline $\mathrm{HCO}_{3}^{-}$ & 0.433 & -0.319 & 0.960 & 0.047 & 0.804 & 0.985 & 0.784 & 0.960 & 0.935 & 0.712 \\
\hline $\mathrm{CO}_{3}^{2-}$ & 0.505 & 0.690 & -0.185 & 0.473 & -0.403 & -0.155 & -0.260 & -0.185 & -0.090 & -0.199 \\
\hline Variables & $\mathrm{Ca}$ & $\mathrm{Mg}$ & $\mathrm{F}^{-}$ & $\mathrm{Cl}^{-}$ & $\mathrm{Br}^{-}$ & $\mathrm{NO}_{3}^{-}$ & $\mathrm{PO}_{4}^{-3}$ & $\mathrm{SO}_{4}{ }^{2-}$ & $\mathrm{HCO}_{3}^{-}$ & $\mathrm{CO}_{3}{ }^{2-}$ \\
\hline \multicolumn{11}{|l|}{ Temp } \\
\hline \multicolumn{11}{|l|}{$\mathrm{pH}$} \\
\hline \multicolumn{11}{|l|}{$\mathrm{EC}$} \\
\hline \multicolumn{11}{|l|}{ DO } \\
\hline \multicolumn{11}{|l|}{ Acidity } \\
\hline \multicolumn{11}{|l|}{ Alka. } \\
\hline \multicolumn{11}{|l|}{$\mathrm{TH}$} \\
\hline \multicolumn{11}{|l|}{ TDS } \\
\hline \multicolumn{11}{|l|}{$\mathrm{Na}$} \\
\hline \multicolumn{11}{|l|}{ K } \\
\hline $\mathrm{Ca}$ & 1 & & & & & & & & & \\
\hline $\mathrm{Mg}$ & 0.586 & 1 & & & & & & & & \\
\hline $\mathrm{F}^{-}$ & 0.343 & 0.396 & 1 & & & & & & & \\
\hline $\mathrm{Cl}^{-}$ & 0.634 & 0.685 & 0.719 & 1 & & & & & & \\
\hline $\mathrm{Br}^{-}$ & 0.700 & 0.487 & 0.758 & 0.828 & 1 & & & & & \\
\hline $\mathrm{NO}_{3}^{-}$ & 0.073 & 0.679 & -0.090 & 0.367 & -0.040 & 1 & & & & \\
\hline $\mathrm{PO}_{4}^{3-}$ & 0.095 & 0.705 & -0.107 & 0.397 & 0.003 & 0.941 & 1 & & & \\
\hline $\mathrm{SO}_{4}^{2-}$ & -0.119 & 0.321 & -0.535 & -0.342 & -0.479 & 0.576 & 0.577 & 1 & & \\
\hline $\mathrm{HCO}_{3}^{-}$ & 0.766 & 0.606 & 0.834 & 0.877 & 0.863 & 0.056 & 0.042 & -0.444 & 1 & \\
\hline $\mathrm{CO}_{3}^{2-}$ & -0.171 & -0.321 & -0.199 & -0.146 & 0.021 & -0.165 & -0.077 & -0.099 & -0.323 & 1 \\
\hline
\end{tabular}

Bold values are positively correlated and above 0.50

(PCs) were considered for both the seasons to explain $87.429 \%$ of the total variance of pre-monsoon season and $87.293 \%$ of the post-monsoon season. In pre-monsoon dataset, $54.529 \%$ of variances are explained by $\mathrm{PC} 1,22.527 \%$ by PC2 and $10.374 \%$ by PC 3 , respectively, and in post-monsoon season $57.197 \%$ variances are explained by PC1, 22.680\% by PC2 and $7.417 \%$ by PC3, respectively (Table 3 ). The factor loadings are classified as 'strong', 'moderate' and 'weak' on the basis of their absolute loading values $>0.75,0.75-0.50$ and 0.50-0.30, respectively (Liu et al. 2003; Wang et al. 
Table 2 Pearson correlation matrix of pre-monsoon water parameters

\begin{tabular}{|c|c|c|c|c|c|c|c|c|c|c|}
\hline Variables & Temp & $\mathrm{pH}$ & $\mathrm{EC}$ & DO & Acidity & Alka. & $\mathrm{TH}$ & TDS & $\mathrm{Na}$ & K \\
\hline Temp & 1 & & & & & & & & & \\
\hline $\mathrm{pH}$ & -0.125 & 1 & & & & & & & & \\
\hline $\mathrm{EC}$ & 0.716 & -0.479 & 1 & & & & & & & \\
\hline DO & -0.584 & 0.766 & -0.845 & 1 & & & & & & \\
\hline Acidity & 0.504 & -0.720 & 0.804 & -0.862 & 1 & & & & & \\
\hline Alka. & 0.733 & -0.313 & 0.924 & -0.654 & 0.691 & 1 & & & & \\
\hline $\mathrm{TH}$ & 0.646 & -0.479 & 0.949 & -0.768 & 0.790 & 0.880 & 1 & & & \\
\hline TDS & 0.716 & -0.479 & 1.000 & -0.845 & 0.804 & 0.924 & 0.949 & 1 & & \\
\hline $\mathrm{Na}$ & 0.520 & -0.116 & 0.729 & -0.496 & 0.486 & 0.795 & 0.572 & 0.729 & 1 & \\
\hline $\mathrm{K}$ & 0.531 & -0.621 & 0.718 & -0.906 & 0.691 & 0.521 & 0.622 & 0.718 & 0.553 & 1 \\
\hline $\mathrm{Ca}$ & 0.339 & -0.754 & 0.548 & -0.738 & 0.756 & 0.387 & 0.637 & 0.548 & 0.195 & 0.736 \\
\hline $\mathrm{Mg}$ & 0.610 & -0.052 & 0.731 & -0.461 & 0.448 & 0.843 & 0.612 & 0.731 & 0.833 & 0.378 \\
\hline F- & 0.491 & -0.224 & 0.710 & -0.375 & 0.556 & 0.799 & 0.676 & 0.710 & 0.745 & 0.258 \\
\hline $\mathrm{Cl}^{-}$ & 0.616 & -0.243 & 0.856 & -0.740 & 0.526 & 0.735 & 0.708 & 0.856 & 0.804 & 0.773 \\
\hline $\mathrm{Br}-$ & 0.170 & -0.167 & 0.340 & -0.333 & 0.334 & 0.360 & 0.163 & 0.340 & 0.756 & 0.466 \\
\hline $\mathrm{NO}_{3}^{-}$ & 0.283 & -0.592 & 0.427 & -0.777 & 0.468 & 0.121 & 0.363 & 0.427 & 0.053 & 0.817 \\
\hline $\mathrm{PO}_{4}^{3-}$ & 0.402 & -0.554 & 0.515 & -0.815 & 0.494 & 0.224 & 0.447 & 0.515 & 0.154 & 0.867 \\
\hline $\mathrm{SO}_{4}^{3-}$ & 0.100 & -0.485 & -0.068 & -0.385 & 0.200 & -0.305 & -0.008 & -0.068 & -0.520 & 0.396 \\
\hline $\mathrm{HCO}_{3}^{-}$ & 0.733 & -0.313 & 0.924 & -0.654 & 0.691 & 1.000 & 0.880 & 0.924 & 0.795 & 0.521 \\
\hline Variables & $\mathrm{Ca}$ & $\mathrm{Mg}$ & $\mathrm{F}^{-}$ & & & & $\mathrm{O}_{3}^{-}$ & $\mathrm{PO}_{4}{ }^{3-}$ & $\mathrm{SO}_{4}^{2-}$ & $\mathrm{HCO}_{3}^{-}$ \\
\hline
\end{tabular}

Temp

$\mathrm{pH}$

$\mathrm{EC}$

DO

Acidity

Alka.

$\mathrm{TH}$

TDS

$\mathrm{Na}$

K

$\mathrm{Ca} \quad 1$

$\mathrm{Mg} \quad-0.012 \quad \mathbf{1}$

$\mathrm{F}^{-} \quad 0.197$

$\mathrm{Cl}^{-} \quad 0.312$

$\mathrm{Br}^{-} \quad 0.073$

$\mathrm{NO}_{3}{ }^{-} \quad 0.579$

$\mathrm{PO}_{4}^{3-} \quad 0.604$

$\mathrm{SO}_{4}^{3-} \quad 0.529$

$\mathrm{HCO}_{3}^{-}$

0.387

\begin{tabular}{rr}
$\mathbf{0 . 7 4 5}$ & \multicolumn{1}{l}{$\mathbf{1}$} \\
$\mathbf{0 . 7 2 0}$ & 0.515 \\
0.608 & 0.511 \\
0.021 & -0.197 \\
0.108 & -0.120 \\
-0.478 & -0.533 \\
$\mathbf{0 . 8 4 3}$ & $\mathbf{0 . 7 9 9}$
\end{tabular}

\begin{tabular}{|c|c|}
\hline 1 & \\
\hline 0.509 & 1 \\
\hline 0.526 & 0.102 \\
\hline 0.619 & 0.120 \\
\hline-0.125 & -0.345 \\
\hline 0.735 & 0.3 \\
\hline
\end{tabular}

1

0.9851

Values in bold are different from 0 with a significance level alpha $=0.01$

2017). In this study, the loadings of PCs for the first two components, which is accounted for $77.056 \%$ of pre-monsoon and $79.876 \%$ of post-monsoon of total variances, are explained and have been employed in biplots (Fig. 6). Screen plots of two different seasons (Fig. 7) have also been used to depict the change of eigenvalues of all the components (Helena et al. 2000). It is evident that PC1 of pre-monsoon season dominantly contains acidity, alkalinity, hardness, TDS, $\mathrm{Na}, \mathrm{K}, \mathrm{Ca}, \mathrm{Mg}$, fluoride, chloride and bromide and PC1 of post-monsoon season contains EC, acidity, alkalinity, hardness, $\mathrm{Na}$, K, chloride and bicarbonate as dominant variables. In both the seasons, the variables are purely hydrochemical and are supposed to originate from the geological process, indicating geogenic sources. In PC2 of both the 
Table 3 Rotated component matrix of chemical data of pre-monsoon and post-monsoon season

Pre-monsoon season Biplot (axes F1 and F2: $77.06 \%$ )

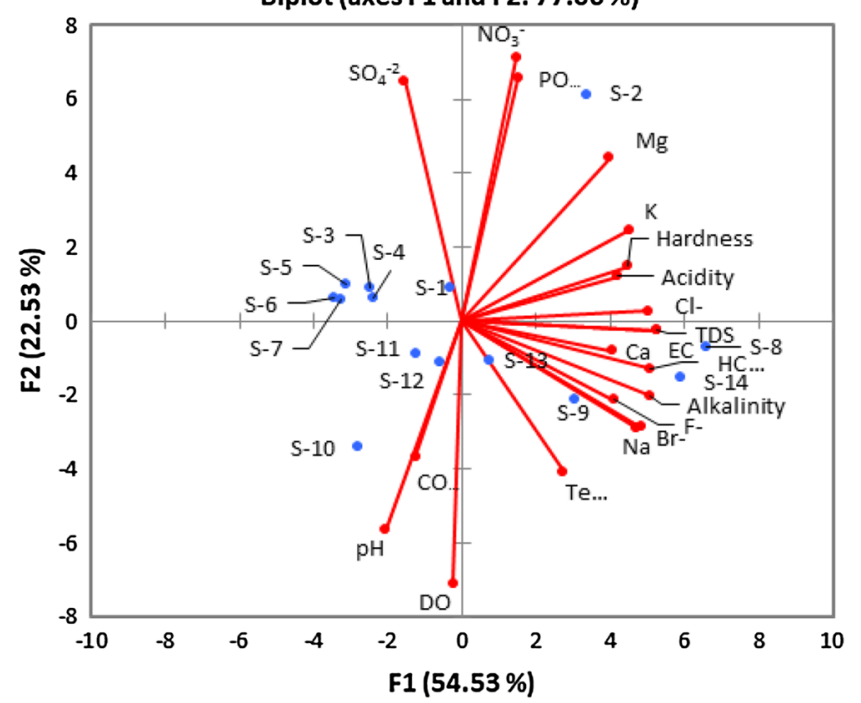

Post-monsoon season Biplot (axes F1 and F2: $79.88 \%$ )

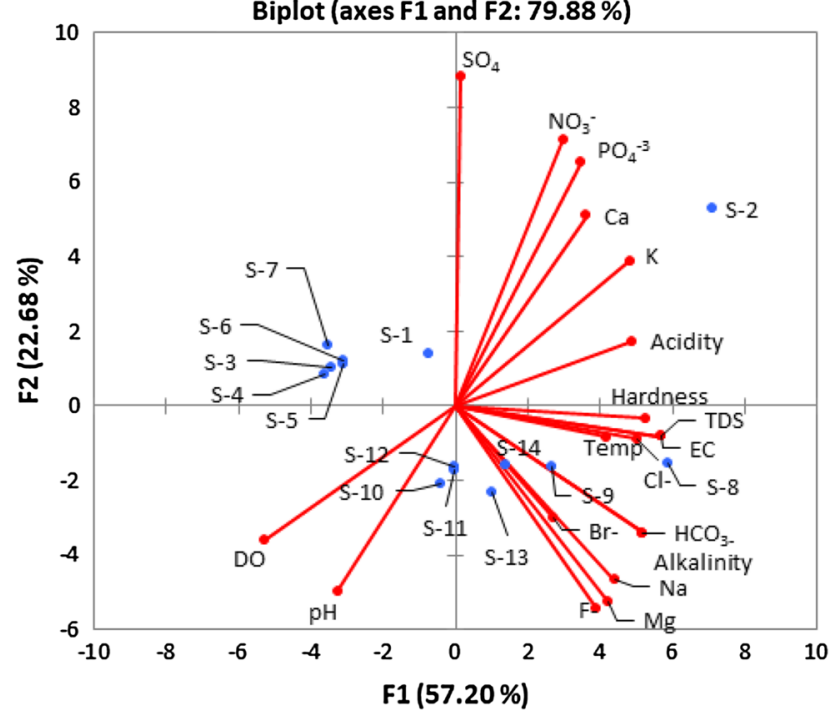

Fig. 6 Biplots of the water quality variables of pre-monsoon and post-monsoon seasons 


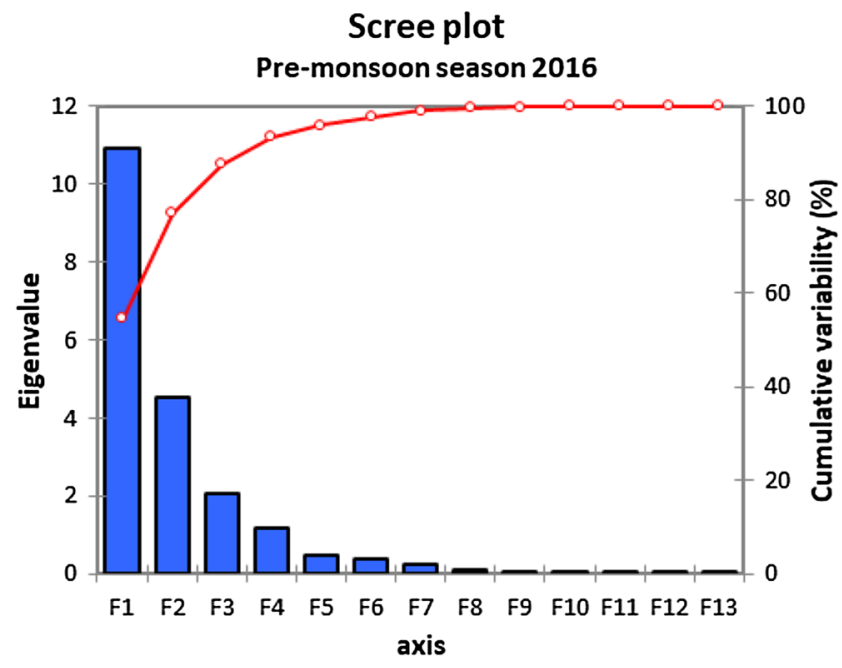

Fig. 7 Scree plots of pre-monsoon and post-monsoon seasons

seasons, sulphate, nitrate and phosphate are dominant factors, which are generally contributed by fertilisers (both from agricultural and industrial), indicating anthropogenic influences (Helena et al. 2000).

The EC, which indirectly signifies the concentration of salt content in water, is an important parameter for evaluating the suitability of water for irrigation purposes. Generally, water of EC less than $2250 \mu \mathrm{S} / \mathrm{cm}$ is considered suitable all irrigation purposes, with a few exception, e.g. very sensitive crops and highly clayey soil (Haritash et al. 2016). Water is classified into three categories based on the electrical conductivity (EC) values: (1) no problems $(<700 \mu \mathrm{S} / \mathrm{cm})$; (2) gradual increasing problems from the continuous use of water (700-3000 $\mu \mathrm{S} / \mathrm{cm})$ and (3) immediate development of severe problems $(>3000 \mu \mathrm{S} / \mathrm{cm}$ ) (Ayers and Westcot 1976; FAO 2008). The ideal value of EC considered by Richards is less than $750 \mu \mathrm{S} / \mathrm{cm}$ (Richards 1954). In our study, EC (in $\mu \mathrm{S} / \mathrm{cm}$ ) values varied from 80.43 to $272.80 \mu \mathrm{S} / \mathrm{cm}$ with a mean value of $142.26 \mu \mathrm{S} / \mathrm{cm}$ in the pre-monsoon season and varied from 96.33 to $227.87 \mu \mathrm{S} / \mathrm{cm}$ with a mean value of $146.29 \mu \mathrm{S} / \mathrm{cm}$ in the post-monsoon season. EC values of all the water samples are below $750 \mu \mathrm{S} / \mathrm{cm}$, complying beautifully with both Richards value and FAO regulation and indicate good quality of irrigation water.

The normal $\mathrm{pH}$ range required for irrigation water is 6.5-8.4 (Ayers and Westcot 1976). The $\mathrm{pH}$ ranges for domestic and other purposes are: 6.5-8.5, maximum desirable limit; 6.5-9.2, maximum permissible limit by WHO (2008); and 6.5-8.5, maximum desirable limit by BIS (2012) (Singh et al. 2008). All the $\mathrm{pH}$ values of the water samples are greater than 7.0 indicating slight alkaline water. The $\mathrm{pH}$ values range from 7.3 to 9.7 in the pre-monsoon period and 7.4 to 9.0 in the post-monsoon period. Eleven (78.57\%) water samples out of 14 are in the normal ranges of $\mathrm{pH}$,

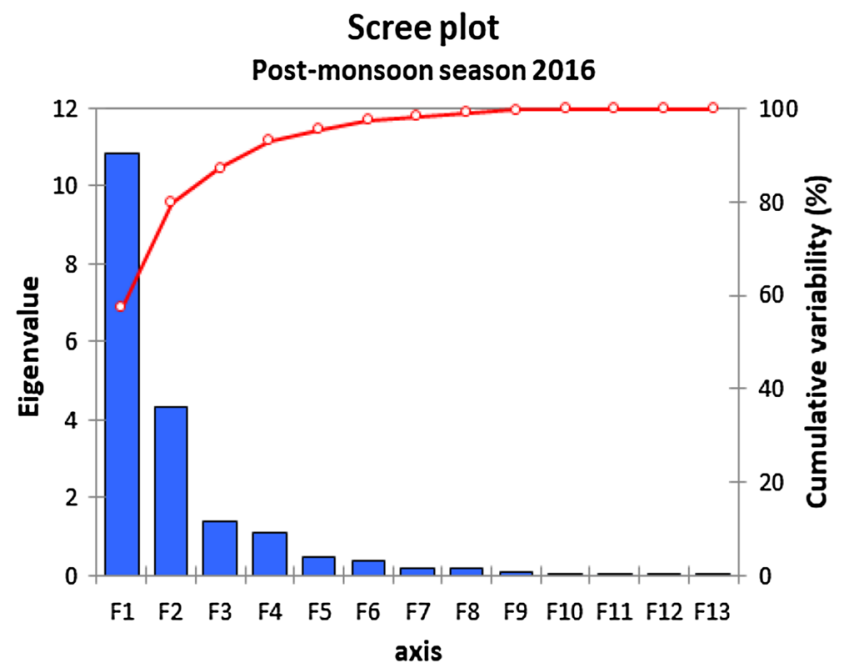

and water of $3(21.42 \%)$ sampling stations are beyond the normal range and are not suitable for irrigation purposes of pre-monsoon period. $92.85 \%$ water samples are in normal range and $7.14 \%$ are not in normal range of post-monsoon period. Sampling stations S-6, S-9, S-10 in pre-monsoon period and sampling station $\mathrm{S}-10$ in post-monsoon period are not suitable for their elevated $\mathrm{pH}$ values. The results are also in good concordance with the maximum desirable limit of WHO (2008) and BIS (2012).

The waters are classified for irrigational purpose according to the SAR values (Richards 1954). The SAR values of the Mahananda River water range from 0.22 to 1.58 in premonsoon season (Table 4) and 0.46 to 1.32 in post-monsoon season (Table 5). According to Richard's classification, all the samples (S-1 to S-14) classified as 'excellent' for irrigation (Sundaray et al. 2009). Spatial variations of the SAR values of both the seasons along the sampling stations have been shown by geospatial map (Fig. 10).

US Salinity Laboratory (USSL) diagrams were used to evaluate the suitability of water for irrigation use for both the seasons. USSL diagrams are made by plotting the sodium absorption ratio (SAR) values against electrical conductivities data (Figs. 8, 9) on a two-dimensional graph (Richards 1954). In this study, only 2 samples (14.28\%) out of the 14 samples of pre-monsoon season fall in the category of $\mathrm{C} 2 \mathrm{~S} 1$, indicating medium salinity/low sodium type water. Rest 12 samples $(85.71 \%$ ) of pre-monsoon season and all the 14 samples of post-monsoon season fall in the category in low salinity/low sodium types, indicating the water suitable for irrigational uses (Singh et al. 2008; Haritash et al. 2016).

Mahananda River water samples are classified with respect to per cent sodium and are shown in Tables 4 and 5. According to Wilcox (1955) classification, out of the 14 samples of the pre-monsoon season, $42.85 \%$ are in excellent 

indices of pre-monsoon season for water quality assessment
Table 4 Values of various
Table 5 Values of various indices of post-monsoon season for water quality assessment

\begin{tabular}{lrrrrrrrrrrrrr}
\hline S. sites & pH & \multicolumn{1}{l}{ EC } & SAR & Na\% & RSC & RSBC & MH & KI & PI & PS & LI & AI & RSI \\
\hline 1 & 8.2 & 138.46 & 0.35 & 16.33 & -0.34 & 0.14 & 33.57 & 0.21 & 73.57 & 0.19 & -0.7 & 11.0 & 9.6 \\
2 & 7.3 & 206.83 & 0.56 & 21.28 & -0.53 & 0.28 & 45.71 & 0.30 & 65.97 & 0.47 & -1.6 & 10.1 & 10.6 \\
3 & 7.9 & 80.43 & 0.22 & 12.31 & -0.43 & -0.11 & 30.99 & 0.15 & 73.78 & 0.13 & -1.4 & 10.3 & 10.7 \\
4 & 8.3 & 85.36 & 0.26 & 14.25 & -0.38 & -0.05 & 30.99 & 0.18 & 76.55 & 0.13 & -0.8 & 10.9 & 9.9 \\
5 & 8.0 & 81.50 & 0.24 & 14.18 & -0.33 & -0.09 & 25.20 & 0.18 & 80.56 & 0.12 & -1.4 & 10.4 & 10.8 \\
6 & 8.6 & 82.60 & 0.26 & 15.11 & -0.28 & -0.03 & 25.20 & 0.19 & 83.69 & 0.12 & -0.5 & 11.2 & 9.6 \\
7 & 8.3 & 82.77 & 0.27 & 15.87 & -0.18 & -0.02 & 18.34 & 0.20 & 90.68 & 0.12 & -0.8 & 10.9 & 9.9 \\
8 & 7.4 & 272.80 & 1.58 & 46.14 & 1.03 & 1.52 & 33.57 & 0.93 & 100.23 & 0.42 & -1.3 & 10.4 & 9.9 \\
9 & 9.0 & 203.06 & 1.16 & 38.43 & 0.40 & 0.89 & 33.57 & 0.68 & 91.40 & 0.25 & 0.3 & 12.0 & 8.3 \\
10 & 9.7 & 98.60 & 0.61 & 29.96 & 0.39 & -0.31 & 18.34 & 0.46 & 77.28 & 0.15 & 0.8 & 12.4 & 8.1 \\
11 & 8.4 & 120.03 & 0.77 & 33.00 & -0.05 & 0.27 & 30.99 & 0.53 & 92.06 & 0.18 & -0.5 & 11.2 & 9.4 \\
12 & 8.2 & 129.63 & 0.91 & 37.41 & 0.09 & 0.33 & 25.20 & 0.66 & 97.79 & 0.22 & -0.7 & 11.0 & 9.6 \\
13 & 7.9 & 147.20 & 0.90 & 34.68 & 0.04 & 0.28 & 20.17 & 0.58 & 90.21 & 0.25 & -0.9 & 10.7 & 9.6 \\
14 & 8.3 & 262.40 & 1.01 & 30.81 & 0.10 & 0.66 & 25.20 & 0.48 & 74.76 & 0.37 & 0.0 & 11.7 & 8.2 \\
\hline
\end{tabular}

\begin{tabular}{lrrrrrrrrrrrrr}
\hline S. sites & pH & EC & SAR & Na\% & RSC & RSBC & MH & KI & \multicolumn{1}{l}{ PI } & PS & LI & AI & RSI \\
\hline 1 & 8.2 & 134.37 & 0.52 & 22.95 & 0.13 & 0.45 & 25.20 & 0.32 & 88.30 & 0.16 & -0.7 & 11.1 & 9.6 \\
2 & 7.4 & 227.87 & 0.93 & 30.46 & -0.07 & 0.49 & 32.04 & 0.50 & 75.61 & 0.44 & -1.2 & 10.7 & 9.7 \\
3 & 8.1 & 96.47 & 0.51 & 26.28 & 0.18 & 0.51 & 40.25 & 0.40 & 107.51 & 0.15 & -0.9 & 10.9 & 9.9 \\
4 & 8.3 & 96.33 & 0.46 & 23.89 & 0.10 & 0.51 & 45.71 & 0.35 & 100.85 & 0.13 & -0.7 & 11.1 & 9.7 \\
5 & 8.2 & 102.30 & 0.62 & 28.02 & -0.13 & 0.20 & 30.99 & 0.43 & 87.96 & 0.14 & -1.0 & 10.9 & 10.2 \\
6 & 8.1 & 101.43 & 0.64 & 29.36 & 0.09 & 0.34 & 25.20 & 0.46 & 96.85 & 0.14 & -1.0 & 10.9 & 10.1 \\
7 & 8.1 & 103.40 & 0.71 & 32.29 & 0.18 & 0.34 & 18.34 & 0.54 & 102.42 & 0.14 & -1.0 & 10.9 & 10.1 \\
8 & 7.4 & 221.90 & 1.21 & 37.29 & 0.35 & 1.16 & 45.71 & 0.65 & 84.75 & 0.21 & -1.5 & 10.4 & 10.3 \\
9 & 8.1 & 176.15 & 1.30 & 40.24 & 0.17 & 0.73 & 37.09 & 0.74 & 86.40 & 0.22 & -0.8 & 11.1 & 9.6 \\
10 & 9.0 & 139.75 & 1.25 & 42.86 & 0.35 & 1.00 & 57.40 & 0.83 & 98.44 & 0.20 & 0.1 & 11.9 & 8.8 \\
11 & 8.4 & 144.90 & 1.31 & 44.62 & 0.29 & 0.86 & 54.11 & 0.90 & 99.16 & 0.21 & -0.5 & 11.3 & 9.4 \\
12 & 8.4 & 147.25 & 1.32 & 45.07 & 0.36 & 0.93 & 54.11 & 0.91 & 101.06 & 0.22 & -0.5 & 11.3 & 9.4 \\
13 & 8.3 & 158.35 & 1.19 & 40.35 & 0.47 & 1.28 & 62.74 & 0.74 & 96.40 & 0.21 & -0.6 & 11.3 & 9.4 \\
14 & 8.4 & 197.60 & 0.82 & 33.10 & 0.60 & 1.16 & 48.54 & 0.54 & 103.34 & 0.22 & -0.5 & 11.4 & 9.3 \\
\hline
\end{tabular}

Fig. 8 USSL diagram of samples of pre-monsoon season 
Fig. 9 USSL diagram of samples of post-monsoon season
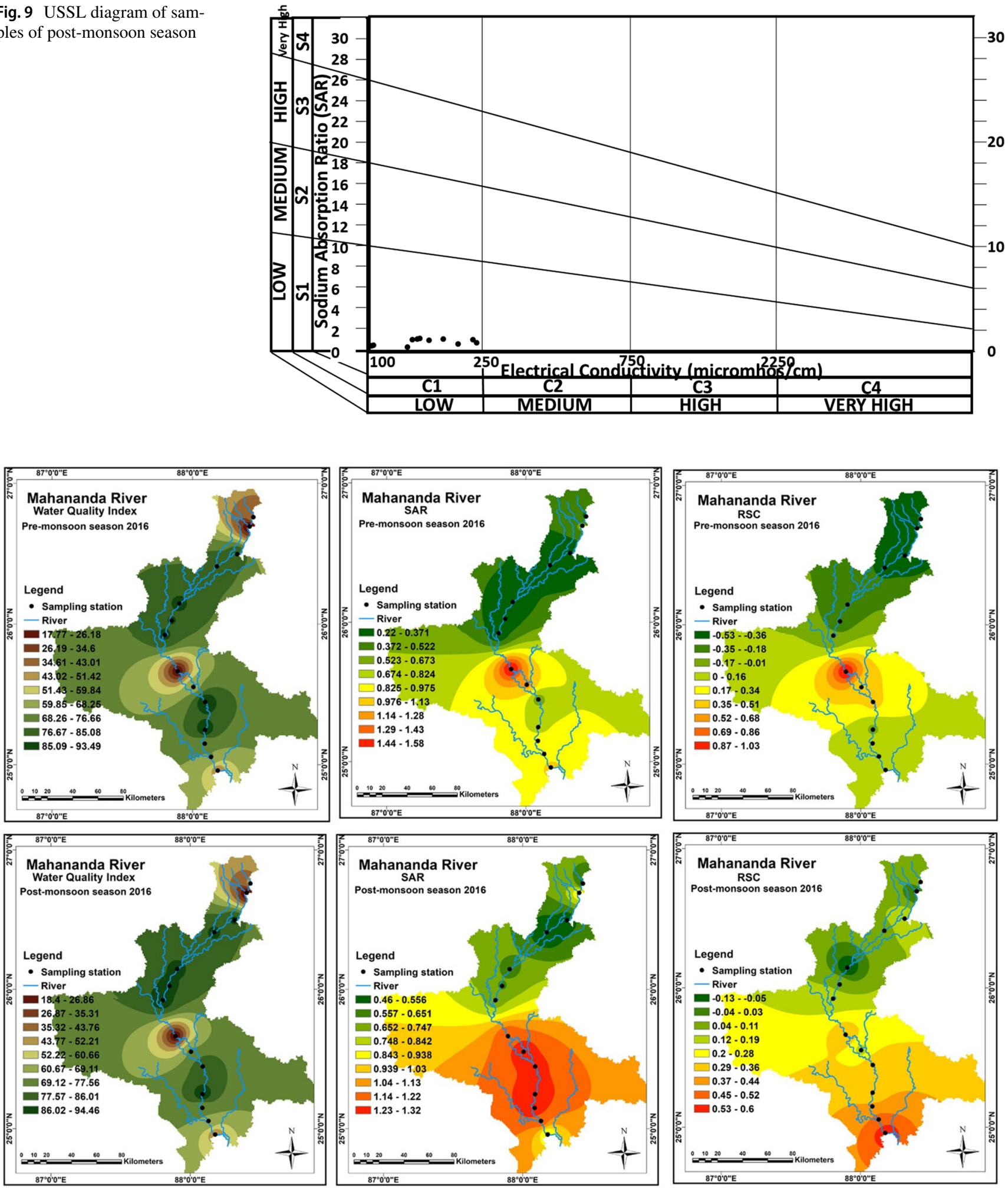

Fig. 10 Spatial variations of water quality index (WQI), sodium adsorption ratio (SAR) and residual sodium carbonate (RSC)

category, $50.0 \%$ are in good category and $7.14 \%$ are in permissible category. In the post-monsoon season, $64.28 \%$ samples are in good category and $35.71 \%$ are in the permissible category. It is observed that the post-monsoon water is worse than the pre-monsoon one, whereas the reverse trend is expected. The effect of dilution or the washing out of 
the sodium with the flow of heavy water during monsoon season is not significant here. The possible reason of higher sodium in post-monsoon water may be the input of sodium through surface run-off of the basin area. According to Eaton (1950) classification, the water is safe $(\mathrm{Na} \%<60)$ for both pre-monsoon and post-monsoon season.

According to Wilcox (1955) of US Salinity Laboratory, a RSC value of less than $1.25 \mathrm{meq} / \mathrm{L}$ is safe for irrigational activity, a value of $1.25-2.5 \mathrm{meq} / \mathrm{L}$ is marginally suitable, and a value greater than $2.5 \mathrm{meq} / \mathrm{L}$ is unsuitable for irrigation (Wilcox 1955). In this study, the water samples have been found to have RSC values from -0.53 to $1.03 \mathrm{meq} / \mathrm{L}$ in pre-monsoon and -0.18 to $0.60 \mathrm{meq} / \mathrm{L}$ in post-monsoon seasons. RSC values of all the samples are less than $1.25 \mathrm{meq} / \mathrm{L}$, indicating the water qualities are 'safe' for irrigation. Sometimes, the RSC values of water samples are negative, which indicate that the calcium and magnesium have not been precipitated out (Tiwari and Manzoor 1988; Sundaray et al. 2009; Srinivasamoorthy et al. 2014). Exact variations of RSC values of both seasons have been shown by IDW interpolation map (Fig. 10).
Gupta and Gupta (1987) proposed the residual sodium bicarbonate (RSBC) index to express the alkalinity hazard. Generally, bicarbonate concentration greater than $10.0 \mathrm{meq} / \mathrm{L}$ is likely to affect plant growth in a number of ways. The RSBC index values of $<5 \mathrm{mg} / \mathrm{L}$ were considered satisfactory (Ravikumar et al. 2011). In this study, the RSBC values range from -0.31 to $1.52 \mathrm{meq} / \mathrm{L}$ in the pre-monsoon season and 0.20 to $1.28 \mathrm{meq} / \mathrm{L}$ in the postmonsoon season. The RSBC values of all the samples of both seasons are significantly below the satisfactory value and can be used safely for irrigational purposes.

Since higher concentration of $\mathrm{Mg}$ ion present in water adversely affects the soil quality and crop yield, magnesium hazard $(\mathrm{MH})$ was also evaluated for all the water samples. The $\mathrm{MH}$ values range from 18.34 to $45.71 \%$ in pre-monsoon season and $18.34-62.74 \%$ in the post-monsoon season. $\mathrm{MH}$ values above $50 \%$ adversely affect the crop yield and are not suitable for irrigation (Sundaray et al. 2009). All the MH values of this study of pre-monsoon season are below $50 \%$. Only four samples $(28.57 \%)$ of post-monsoon season, i.e. S-10, S-11, S-12, S-13, have
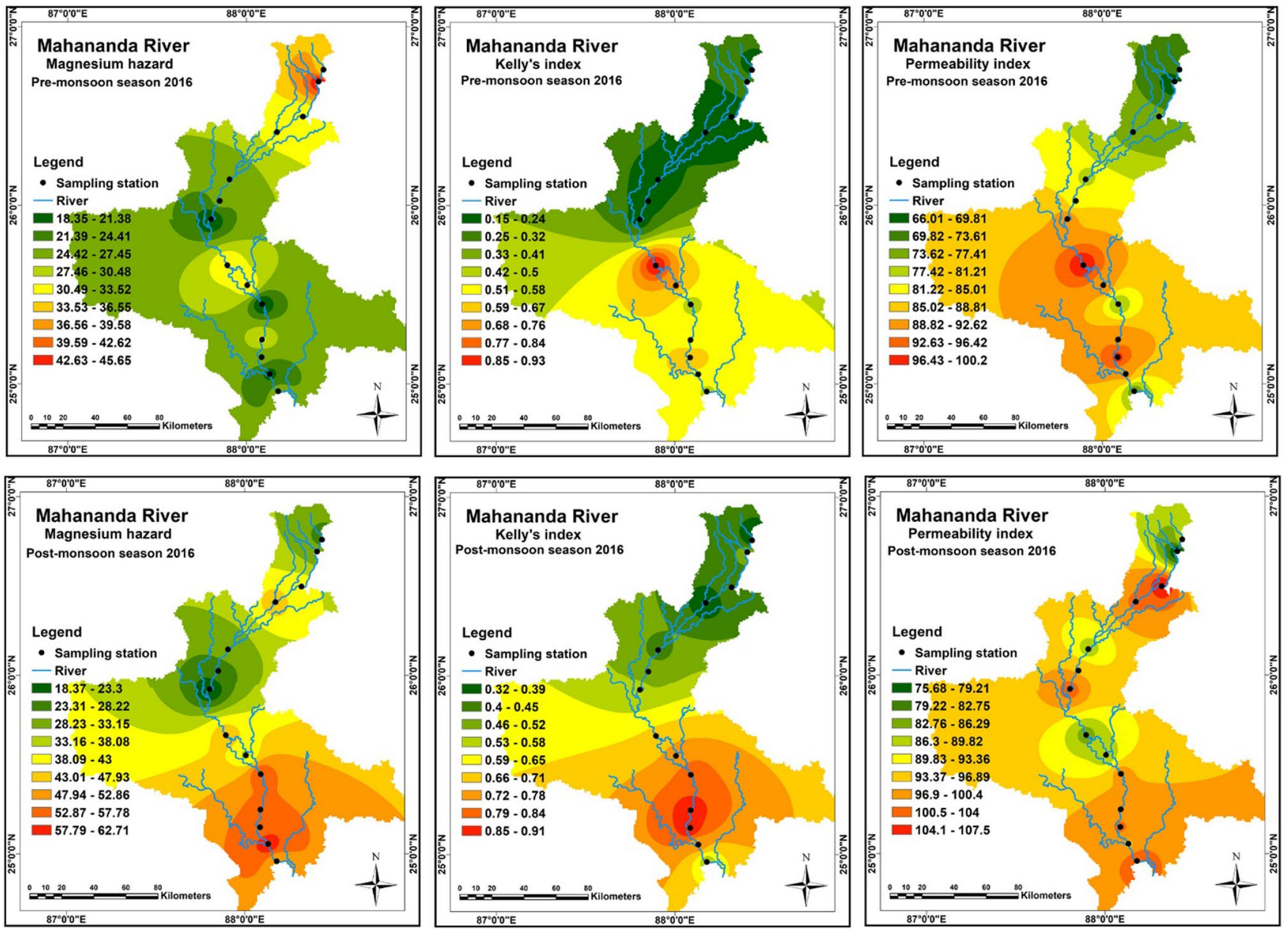

Fig. 11 Spatial variations of magnesium hazard (MH), Kelly's index (KI) and permeability index (PI) 
MH values above $50 \%$ and are not suitable for irrigation. IDW variations of MH values of pre-monsoon and postmonsoon seasons are shown in Fig. 11.

Kelly's index indicates relative sodium quantity against calcium and magnesium and helps us to determine the suitability of the water for agricultural purposes. The values of Kelly's index less than one $(\mathrm{KI}<1)$ are suitable for irrigation, greater than one $(\mathrm{KI}>1)$ indicates excess sodium in water and not suitable for irrigational purpose, and values less than two $(\mathrm{KI}<2)$ signifies sodium deficiency in water and is not suitable for irrigation (Kelly 1940; Sundaray et al. 2009; Srinivasamoorthy et al. 2014). In this study, the values of Kelly's index range from 0.15 to 0.93 in the pre-monsoon season and from 0.32 to 0.91 in the post-monsoon season. The ranges indicate that the water of both the seasons is safe for irrigational purposes. Geospatially, the variations of values are shown in the IDW map (Fig. 11).

Permeability index (PI) values of Mahananda River water ranged from 65.97 to 100.23 in pre-monsoon season (Table 4) and from 75.61 to 107.51 in the post-monsoon season (Table 5). Ten samples fall into the class I, and four samples (S-1, S-2, S-3 and S-4) fall in the class II in premonsoon season. All the samples of the post-monsoon season fall in the class I (Sundaray et al. 2009; Das and Nag 2015). Variations of the PI values along the sampling stations are shown by IDW map (Fig. 11). According to the PI analysis, the post-monsoon water is better than pre-monsoon one, possibly because of the addition of large amount of fresh rain water.

Doneen (1964) explained that the suitability of water for irrigation is not dependent on the total concentration of soluble salts, as low solubility salts precipitate out and deposited on the soil every year. Actually, low salt containing water is suitable for irrigational purposes. Potential salinity (PS) of the water samples of the Mahananda River varied from 0.12 to 0.47 in the pre-monsoon season (Table 4 ) and from 0.13 to 0.44 in the post-monsoon season (Table 5) and is considered fair low. The measurement of PS is very much significant in the estuarine region because of the high salt content from the sea water.

Mahananda River water was analysed to evaluate the suitability for industrial use on the basis of some well-known indices, viz. Langelier Saturation Index (LI), aggressive index (AI) and Ryznar Stability index (RSI). The values of LI varied from -1.6 to 0.8 in pre-monsoon season (Table 4) and from -1.5 to 0.1 in the post-monsoon season (Table 5), indicating the water moderately aggressive to non-aggressive in nature. Usually, non-aggressive water is preferred in industries for its uses. Aggressive index (AI) values are also in good concordance with the LI values. The AI values ranged from 10.14 to 12.4 in the pre-monsoon season (Table 4) and ranged from 10.40 to 11.90 in the post-monsoon season (Table 5). The AI values also indicate that the
Table 6 Classification of water according to corrosive characteristics (Langelier 1936)

\begin{tabular}{lll}
\hline $\begin{array}{l}\text { Corrosive characteristics and } \\
\text { categories }\end{array}$ & $\begin{array}{l}\text { Langelier index (LI) } \\
\text { ranges }\end{array}$ & $\begin{array}{l}\text { Aggressive } \\
\text { index (AI) } \\
\text { ranges }\end{array}$ \\
\hline Highly aggressive & $<-2.0$ & $<10.0$ \\
Moderately aggressive & -2.0 to 0.0 & 10.0 to 12.0 \\
Non-aggressive & $>0.0$ & $>12.0$ \\
\hline
\end{tabular}

Table 7 Classification of water for industrial purposes based on RSI values

\begin{tabular}{llll}
\hline RSI & $\begin{array}{l}\text { Inference (Ryznar and } \\
\text { Langelier 1944) }\end{array}$ & RSI & $\begin{array}{l}\text { Inference (Haritash } \\
\text { et al. 2016) }\end{array}$ \\
\hline$<5.5$ & Heavy scale will form & $4-5$ & Heavy scale \\
$5.5-6.2$ & Scale will form & $5-6$ & Light scale \\
$6.2-6.8$ & No difficulties & $6-7$ & Little scale or corrosion \\
$6.8-8.5$ & Water is aggressive & $7-7.5$ & Corrosion significant \\
$>8.5$ & Water is very aggressive & $7.5-9$ & Heavy corrosion \\
& & $>9$ & Corrosion intolerable \\
\hline
\end{tabular}

water of the Mahananda River is moderately aggressive and non-aggressive at S-10 of pre-monsoon season (Table 6). According to Ryznar Stability Index (RSI), proposed by Ryznar and Langelier (1944), only the water at S-14 is aggressive and the rest samples are very aggressive. However, there is another method in use for classifying industrial water on the basis of RSI in which values greater than 9 (Table 7) are considered corrosion intolerable (Haritash et al. 2016). All the sampling stations except S-9, S-10 and S-14 in the pre-monsoon season and sampling station S-10 in the post-monsoon have RSI values greater than 9 indicating corrosion intolerable.

\section{Conclusion}

In this study, WQI method was applied to investigate the water quality status of Mahananda River. The water quality of the river is generally moderate to good with exception at a few sampling stations which are 'very bad' and 'bad' quality. $\mathrm{pH}$ values were found to exceed marginally the normal range in some sampling stations. According to USSL diagram, two samples of pre-monsoon season fall in the category of $\mathrm{C} 2 \mathrm{~S} 1$ indicating a medium salinity and low sodium type water. In respect of sodium per cent $(\mathrm{Na} \%)$, residual sodium carbonate (RSC) and residual sodium bicarbonate (RSBC), the water is usable for irrigation purposes. $\mathrm{Na} \%$ is higher in post-monsoon season which indicates sodium input into the river from the basin area. The magnesium hazard values of four samples of post-monsoon season have values above 
$50 \%$ and are consider not suitable for irrigation purpose. According to the Kelly's index (KI), permeability index (PI) and potential salinity, the river water is safe for agricultural purposes. Langelier Saturation Index (LI) analysis designated the water as moderately aggressive to non-aggressive in nature restricting the uses for industrial purposes. According to the AI values, the water of the Mahananda River is moderately aggressive and non-aggressive only at S-10 of pre-monsoon season, indicating unsuitability for industries. Ryznar Stability Index (RSI) also expresses the unsuitability for industrial uses. Overall, the water of Mahananda River is good with some exception at places of municipal proximity and places of poor mobility. A few indices that determine the agricultural suitability do not permit the water to be used in irrigation. The water should be used in industry after proper treatment. The water which may be used for drinking and agricultural purposes may not be used in industry. The river needs protection and precautionary management plans.

Acknowledgements We would like to thank the HOD of Department of Environmental Studies, Visva-Bharati, for using their instrumental facilities for the sample analysis. We wish to thank editor and the anonymous reviewers for their suggestions and critical comments.

Open Access This article is distributed under the terms of the Creative Commons Attribution 4.0 International License (http://creativeco mmons.org/licenses/by/4.0/), which permits unrestricted use, distribution, and reproduction in any medium, provided you give appropriate credit to the original author(s) and the source, provide a link to the Creative Commons license, and indicate if changes were made.

\section{References}

Abdul HM, Jaward A, Bahram KM, Abass JK (2010) Evaluating raw and treated water quality of Tigris River within Baghdad by index analysis. J Water Resour Prot 2:629-635

Ameen SMM, Wilde SA, Kabir MZ, Akon E, Chowdhury KR, Khan MSH (2007) Paleoproterozoic granitoids in the basement of Bangladesh: a piece of the Indian shield or an exotic fragment of the Gondwana jigsaw? Gondwana Res 12:380-387. https:// doi.org/10.1016/j.gr.2007.02.001

APHA (2012) Standard methods for the examination of water and wastewater, 22nd edn. American Public Health Association, American Water Works Association, Water Environment Federation, Washington

Arumugam K, Elangovan K (2009) Hydrochemical characteristics and groundwater quality assessment in Tirupur Region, Coimbatore District, Tamil Nadu, India. Environ Geol 58:1509-1520. https://doi.org/10.1007/s00254-008-1652-y

Ayers RS, Westcot DW (1976) Water quality for agriculture. FAO irrigation and drainage. Paper no. (29), rev. (1). U.N. Food and Agriculture Organization, Rome

Banerjee T (1955) Progress report for 1955-1956 field season (Continuation of geological mapping in Sikkim and Kalimpong hills). Geological Survey of India. F. no. 398(10)

Barakat A, Baghdadi ME, Rais J, Aghezzaf B, Slassi MM (2016) Assessment of spatial and seasonal water quality variation of Oum Er Rbia River (Morocco) using multivariate statistical techniques. Int Soil Water Conserv Res. https://doi. org/10.1016/j.iswcr.2016.11.002

Belkhiri L, Boudoukha A, Mouni L (2011) A multivariate statistical analysis of groundwater chemistry data. Int J Environ Res 5(2):537-544

Bhargava DS (1983) Use of water quality index for river classification and zoning of Ganga River. Environ Pollut Ser B Chem Phys 6(1):51-67

BIS (2012) Indian standard, Drinking water-specification (second revision). IS: 10500, Bureau of Indian Standards, New Delhi

Brown RM, McClelland NI, Deininger RA, Tozer RG (1970) A water quality index - do we dare. Water Sew Works 117:339-343

Carpenter S, Caraco NF, Correll DL, Howarth RW, Sharpley AN, Smith VH (1998) Nonpoint pollution of surface waters with phosphorus and nitrogen. Ecol Appl 8(3):559-568

Chapman D (1996) Water quality assessments - a guide to use of biota, sediments and water in environmental monitoring, 2nd edn. UNESCO/WHO/UNEP, E \& FN Spon, London, p 651

Cude CG (2001) Oregon water quality index a tool for evaluating water quality management effectiveness. J Am Water Resour Assoc 37(1):125-137. https://doi. org/10.1111/j.1752-1688.2001.tb05480.x

Das S, Nag SK (2015) Deciphering groundwater quality for irrigation and domestic purposes - a case study in Suri I and II blocks, Birbhum District, West Bengal, India. J Earth Syst Sci 124(5):965-992

Dash AJ (1947) Darjeeling. Bengal district gazetteers superintendent. Government printing Bengal Government Press, Alipore

Doneen LD (1962) The influence of crop and soil on percolating water. In: Proceedings of the Biennial conference on ground water recharge, pp 156-163

Doneen LD (1964) Notes on water quality in agriculture. Water Science and Engineering, University of California, Davis

Eaton FM (1950) Significance of carbonates in irrigated waters. Soil Sci 69:127-128. https://doi.org/10.1097/00010694-19500 2000-00004

Etteieb S, Cherif S, Tarhouni J (2017) Hydrochemical assessment of water quality for irrigation: a case study of the Medjerda River in Tunisia. Appl Water Sci 7:469-480. https://doi.org/10.1007/ s13201-015-0265-3

FAO (2008) Guide for laboratory establishment for plant nutrient analysis. FAO, Rome

Galib SM, Rashid MA, Chaki N, Mohsin ABM, Joadder MAR (2016) Seasonal variation and community structure of fishes in the Mahananda River, Bangladesh. J Fish 4(1):325-334. https://doi. org/10.17017/jfish.v4i1.2016.139

Giridharan L, Venugopal T, Jayaprakash M (2010) Identification and evaluation of hydrogeochemical processes on river Cooum, South India. Environ Monit Assess 162:277-289

Guettaf M, Maoui A, Ihdene Z (2014) Assessment of water quality: a case study of the Seybouse River (North East of Algeria). Water Sci Appl. https://doi.org/10.1007/s13201-014-0245-z

Gupta SK, Gupta IC (1987) Management of saline soils and water. Oxford and IBM Publ. Co, New Delhi, p 399

Haritash AK, Gaur S, Garg S (2016) Assessment of water quality and suitability analysis of River Ganga in Rishikesh, India. Appl Water Sci 6:383-392. https://doi.org/10.1007/s13201-014-0235-1

Helena B, Pardo R, Vega M, Barrado E, Fernandez JM, Fernandez L (2000) Temporal evolution of groundwater composition in an alluvium aquifer (Pisuerga River, Spain) by principal component analysis. Water Res 34(3):807-816

Hem JD (1970) Study and interpretation of the chemical characteristics of natural water. Geological survey water-supply paper 1473. United States government printing office, Washington 
Hem JD (1989) Study and interpretation of the chemical characteristics of natural water, 3rd edn. US Geological Survey Water-Supply paper no 2254, 263

Heroy DC, Kuehl SA, Goodbred SL Jr (2003) Mineralogy of the Ganges and Brahmaputra Rivers: implications for river switching and late quaternary climate change. Sediment Geol 155:343-359. https://doi.org/10.1016/S0037-0738(02)00186-0

Horton RK (1965) An index number system for rating water quality. Water Pollut Control Fed 37:300-306

Igbinosa EO, Okoh AI (2009) Impact of discharge wastewater effluents on the physico-chemical qualities of a receiving watershed in a typical rural community. Int Environ Sci Technol 6:175-182

Jarvie HP, Whitton BA, Neal C (1998) Nitrogen and phosphorus in east coast British rivers: speciation, sources and biological significance. Sci Total Environ 210(211):79-109

Jonnalagadda SB, Mhere G (2001) Water quality of the Odzi River in the eastern highlands of Zimbabwe. Water Res 35(10):2371-2376

Kannel PR, Lee S, Lee YS, Kanel SR, Khan SP (2007) Application of water quality indexes and dissolved oxygen as indicators for river water classification and urban impact assessment. Environ Monit Assess 132:93-110

Kazi T, Arain MB, Jamali MK, Jalbani N, Afridi HI, Sarfraz RA, Baig JA, Shah AQ (2009) Assessment of water quality of polluted lake using multivariate statistical techniques: a case study. Ecotoxicol Environ Saf 72:301-309

Kelly WP (1940) Permissible composition and concentration of irrigated waters. In: Proceedings of the ASCF 66, p 607

Kelly WP (1951) Alkali soils - their formation, properties and reclamation. Reinhold, New York

Khan MYA, Gani KM, Chakrapani GJ (2015) Assessment of surface water quality and its spatial variation. A case study of Ramganga River, Ganga Basin, India. Arab J Geosci. https://doi.org/10.1007/ s12517-015-2134-7

Kumar B, Singh UK (2018) Source apportionment of heavy metals and their ecological risk in a tropical river basin system. Environ Sci Pollut Res. https://doi.org/10.1007/s11356-018-2480-6

Kumar B, Singh UK, Ojha SN (2018) Evaluation of geochemical data of Yamuna River using WQI and multivariate statistical analyses: a case study. Int J River Basin Manag. https://doi. org/10.1080/15715124.2018.1437743

Kumarasamy P, Dahms HU, Jeon HJ, Rajendran A, James RA (2013a) Irrigation water quality assessment-an example from the Tamiraparani river, Southern India. Arab J Geosci. https://doi. org/10.1007/s12517-013-1146-4

Kumarasamy P, James RA, Dahms HU, Byeon CW, Ramesh R (2013b) Multivariate water quality assessment from the Tamiraparani river basin, Southern India. Environ Earth Sci. https://doi.org/10.1007/ s12665-013-2644-0

Langelier WF (1936) The analytical control of anti-corrosion water treatment. J Am Water Work Assoc 28:1500-1521

Lermontov A, Yokoyama L, Lermontov M, Machado MAS (2009) River quality analysis using fuzzy water quality index: Ribeira do Iguape river watershed, Brazil. Ecol Indic 9:1188-1197. https ://doi.org/10.1016/j.ecolind.2009.02.006

Liu CW, Lin KH, Kuo YM (2003) Application of factor analysis in the assessment of groundwater quality in a blackfoot disease area in Taiwan. Sci Total Environ 313:77-89. https://doi.org/10.1016/ S0048-9697(02)00683-6

Manahan SE (2010) Environmental chemistry, 9th edn. CRC Press, Boca Raton, p 52

Mandal DK (2013) River linking and flood management of Mahananda River basin in West Bengal. J Bengal Geogr II(I):1-15 (ISSN 2319-619X)

Misaghi F, Delgosha F, Razzaghmanesh M, Myers B (2017) Introducing a water quality index for assessing water for irrigation purposes: a case study of the Ghezel Ozan River. Sci Total Environ 589:107-116. https://doi.org/10.1016/j.scitotenv.2017.02.226

Mohamed I, Othman F, Ibrahim AIN, Alaa-Eldin ME, Yunus RM (2015) Assessment of water quality parameters using multivariate analysis for Klang River basin, Malaysia. Environ Monit Assess 187:4182. https://doi.org/10.1007/s10661-014-4182-y

Morgan JP, McIntire WG (1959) Quaternary geology of the Bengal basin, East Pakistan and India. Geol Soc Am Bull 70:319-342. https://doi.org/10.1130/0016-7606(1959)70\%5b319:qgotb $\mathrm{b} \% 5 \mathrm{~d} 2.0 . \mathrm{co} ; 2$

Mudgal KD, Kumari M, Sharma DK (2009) Hydrochemical analysis of drinking water quality of Alwar District, Rajasthan. Nat Sci 7(2):30-39

Mukherjee A, Fryar AE, William AT (2009) Geologic, geomorphic and hydrologic framework and evolution of the Bengal basin, India and Bangladesh. J Asian Earth Sci 34:227-244. https:// doi.org/10.1016/j.jseaes.2008.05.011

Nives SG (1999) Water quality evaluation by index in Dalmatia. Water Res 33(16):3423-3440

Ombaka O, Gichumbi JM (2012) Water quality assessment of Ruguti River in Meru South, Kenya. Int J Water Resour Environ Eng 4(12):404-414. https://doi.org/10.5897/IJWREE12.093

Ongley ED (2000) Water quality management: design, financing and sustainability considerations-II. Invited presentation at the World Bank's water week conference: towards a strategy for managing water quality management, 3-4 Apr 2000, Washington, DC USA

Paliwal KV (1972) Irrigation with saline water. Monogram no. 2, new series. IARI, New Delhi, p 198

Pesce SF, Wunderlin DA (2000) Use of water quality indices to verify the impact of Córdoba city (Argentina) on Suquía River. Water Res 34(11):2915-2926

Piper AM (1944) A graphic procedure in the geochemical interpretation of water analysis. Trans Am Geophys Union 25:914-928

Priscoli JD (1998) Water and civilization: using history to reframe water policy debates and to build a new ecological realism. Water Policy 1:623-636

Rakotondrabe F, Ngoupayou JRN, Mfonka Z, Rasolomanana EH, Abolo AJN, Ako AA (2018) Water quality assessment in the Bétaré-Oya gold mining area (East-Cameroon): multivariate statistical analysis approach. Sci Total Environ 610-611:831-844. https://doi.org/10.1016/j.scitotenv.2017.08.080

Ravikumar P, Somashekar RK, Angami M (2011) Hydrochemistry and evaluation of groundwater suitability for irrigation and drinking purposes in the Markandeya River basin, Belgaum District, Karnataka State, India. Environ Monit Assess 173:459-487

Richards LA (1954) Diagnosis and improvement of saline and alkali soils. US Department of Agri. Hand book, no 60

Ryznar JW, Langelier WF (1944) A new index for determining amount of calcium carbonate scale formed by a water [with discussion]. Am Water Works Assoc 36(4):472-486

Sánchez E, Colmenarejo MF, Vicente J, Rubio A, García MG, Travieso L, Borja R (2007) Use of the water quality index and dissolved oxygen deficit as simple indicators of basins pollution. Ecol Indic 7:315-328

Sener S, Sener E, Davraz A (2017) Evaluation of water quality using water quality index (WQI) method and GIS in Aksu River (SW-Turkey). Sci Total Environ 584-585:131-144. https://doi. org/10.1016/j.scitotenv.2017.01.102

Simeonov V, Stratis JA, Samara C, Zachariadis G, Voutsa D, Anthemidis A, Sofoniou M, Kouimtzis T (2003) Assessment of the surface water quality in Northern Greece. Water Res 37:4119-4124

Singh H (1983) Crop production in India. Agric Situat India. 38:635-639 
Singh UK, Kumar B (2017) Pathways of heavy metals contamination and associated human health risk in Ajay River basin, India. Chemosphere 174:183-199. https://doi.org/10.1016/j.chemospher e.2017.01.103

Singh KP, Malik A, Sinha S (2005) Water quality assessment and apportionment of pollution sources of Gomti river (India) using multivariate statistical techniques - a case study. Anal Chim Acta 538(1-2):355-374

Singh AK, Mondal GC, Kumar S, Singh TB, Tewary BK, Sinha A (2008) Major ion chemistry, weathering processes and water quality assessment in upper catchment of Damodar River basin, India. Environ Geol 54:745-758. https://doi.org/10.1007/s0025 4-007-0860-1

Srinivasamoorthy K, Gopinath M, Chidambaram S, Vasanthavigar M, Sarma VS (2014) Hydrochemical characterization and quality appraisal of groundwater from Pungar sub basin, Tamilnadu, India. J King Saud Univ Sci 26:37-52. https://doi.org/10.1016/j. jksus.2013.08.001

Subramani T, Rajmohan N, Elango L (2009) Groundwater geochemistry and identification of hydrogeochemical processes in a hard rock region, Southern India. Environ Monit Assess 162(1-4):123-137

Sundaray SK, Nayak BB, Bhatta D (2009) Environmental studies on river water quality with reference to suitability for agricultural purposes: Mahanadi river estuarine system, India - a case study. Environ Monit Assess 155:227-243. https://doi.org/10.1007/ s10661-008-0431-2

Tiwari TN, Manzoor A (1988) Pollution of Subarnarekha river near Jamshedpur and the suitability of its water for irrigation. Indian J Environ Prot 8(7):494-497

Todd DK (1980) Groundwater hydrology, 2nd edn. Wiley, New York, p 535
Wang Z, Wang Y, Chen L, Yan C, Yan Y, Chi Q (2015) Assessment of metal contamination in coastal sediments of the Maluan Bay (China) using geochemical indices and multivariate statistical approaches. Mar Pollut Bull 99:43-53. https://doi.org/10.1016/j. marpolbul.2015.07.064

Wang J, Liu G, Liu H, Lam PKS (2017) Multivariate statistical evaluation of dissolved trace elements and a water quality assessment in the middle reaches of Huaihe River, Anhui, China. Sci Total Environ. https://doi.org/10.1016/j.scitotenv.2017.01.088

WHO (2008) Guidelines for drinking-water quality: third edition incorporating the first and second addenda. World Health Organization, Geneva

Wilcox LV (1955) Classification and uses of irrigation waters. US Dept. Agric. Circular no. 969, Washington, DC

Yan CA, Zhang W, Zhang Z, Liu Y, Deng C, Nie N (2015) Assessment of water quality and identification of polluted risky regions based on field observations and GIS in the Honghe River Watershed, China. PLoS ONE 10(3):0119130. https://doi.org/10.1371/journ al.pone. 0119130

Zhang Y, Guo F, Meng W, Wang XQ (2009) Water quality assessment and source identification of Daliao river basin using multivariate statistical methods. Environ Monit Assess 152:105-121. https:// doi.org/10.1007/s10661-008-0300-z

Publisher's Note Springer Nature remains neutral with regard to jurisdictional claims in published maps and institutional affiliations. 